\title{
Neuronal Regulation of C-fos, C-jun, and junB Immediate-Early Genes in Rat Adrenal Medulla
}

\author{
Markku Pelto-Huikko, Åke Dagerlind, ${ }^{2}$ Juha Kononen, ${ }^{1}$ Jan M. Lundberg, ${ }^{3}$ Marcello Villar, ${ }^{2}$ Jari Koistinaho, \\ Rodrigo Bravo, ${ }^{4}$ and Tomas Hökfelt ${ }^{2}$ \\ 'Department of Biomedical Sciences, University of Tampere, Tampere, Finland, Departments of ${ }^{2}$ Neuroscience and \\ ${ }^{3}$ Physiology and Pharmacology, Karolinska Institute, Stockholm, Sweden, and ${ }^{4}$ Department of Molecular Biology, \\ Bristol-Meyers Squibb Pharmaceutical Research Institute, Princeton, New Jersey
}

We have applied in situ hybridization histochemistry, Northern analysis, and immunocytochemistry to study the regulation of the immediate-early gene (IEG) c-fos, c-jun, and $j u n B$ mRNAs and the respective proteins in the rat adrenal medulla. Electrophoresis mobility shift assay was used to examine changes in AP-1 DNA binding activity. In nontreated rats the mRNA and protein levels for these three IEGs were low. Reflex stimulation of adrenal medulla elicited by a single capsaicin injection induced a rapid and marked elevation in the mRNA levels for these IEGs. Stimulation with nicotine also caused a drastic increase in the mRNA levels, whereas muscarine only induced moderate elevations. $c$-fos and $c$-jun were induced strongly in adrenaline cells and only weakly in noradrenaline cells. junB was upregulated mainly in adrenaline cells. The AP-1 DNA binding activity was low in control adrenals, whereas a marked increase was observed after nicotine treatment.

Treatment of the animals with a nicotinic (chlorisondamine) or a muscarinic (atropine) receptor antagonist did not change the expression of IEGs studied. The combination of the two drugs, however elevated the mRNA levels for all three IEGs, especially for junB. Pretreatment of the rats with chlorisondamine alone or in combination with atropine diminished the capsaicin-induced increase in c-fos, whereas atropine alone was less efficient. Increase in c-jun mRNA was not affected by these drugs. The capsaicin-induced elevation of junB mRNA levels was not influenced by chlorisondamine or atropine alone, whereas both combined potentiated the effect of capsaicin.

The present results demonstrate that neurotransmitters released from splanchnic nerve terminals induce expression of c-fos, c-jun, and junB in adrenal chromaffin cells which results in increased AP-1 DNA binding activity. Although stimulation of both nicotinic and muscarinic cholinergic receptors may mediate the induction of these IEGs,

\footnotetext{
Received Mar. 9, 1994; revised Aug. 22, 1994; accepted Sept. 6, 1994.

The skillful technical assistance of Ms. Hannele Ylitie, Ms. Katarina Åman, Ms. Siv Nilsson, Ms. Katarina Friberg, and Ms. Marketta Vuorinen is greatly appreciated. Drs. Tiina Henttinen and Antero Salminen are thanked for their help in setting up the EMSA. This study was supported by the Swedish Medical Research Council (04X-2887), Marcus and Marianne Wallenbergs Stiftelse, Sigurd and Elsa Goljes Minne, Svenska Sällskapet för Medicinsk Forskning och Svenska Läkarsällskapet.

Correspondence should be addressed to Markku Pelto-Huikko, Department of Biomedical Sciences, University of Tampere, Box 607, FIN-33101 Tampere, Finland.

Copyright (C) 1995 Society for Neuroscience $0270-6474 / 95 / 151854-15 \$ 05.00 / 0$
}

it is possible that also another neurotransmitter(s), in addition to $\mathrm{ACh}$, released from splanchnic nerve terminals is involved in the regulation of their expression, especially of c-jun and junB.

[Key words: chromaffin cells, preganglionic sympathetic neurons, innervation, $\mathrm{ACh}$, transcription, gene regulation]

Gene transcription is regulated by the combined action of several trans-acting factors on distinct regulatory elements in target genes (Dynan 1989; Lin et al., 1990). The complexity of the intracellular signaling pathways involved in the control of gene expression after extracellular stimulation reflects the heterogeneity of trans-acting factor/enhancer interactions. Several genes coding for transcriptionally active proteins have been characterized during the last decade (Sheng and Greenberg, 1990). One of these transcription factors is the activator protein-1 (AP-1) (Angel et al., 1987; Lee et al., 1987), which is formed by dimeric complexes of the proteins (reviewed in Curran and Franza, 1988; Abate and Curran, 1990; Vogt and Bos, 1990; Angel and Karin, 1991 ) encoded by the fos (c-fos, fos $\mathrm{B}$, fra-1, fra-2) and jun (cjun, jun $\mathrm{B}$, jun D) families of proto-oncogenes (Bohman et al., 1987; Cohen and Curran, 1988; Hirai et al., 1989; Ryder et al., 1989; Zerial et al., 1989; Nishina et al., 1990). Since a great variety of extracellular stimuli elicits their rapid and transient induction in a protein synthesis-independent manner, they have also been referred to as cellular immediate-early genes (IEGs).

The induction of the various members of fos and jun families exhibit differential time course after stimulations, and thus the compositions of AP-1 complexes exhibit dynamic temporal changes (Morgan and Curran, 1991). These complexes vary with regard to their binding affinity and specificity for the variants of AP-1 sites (Rysek and Bravo, 1991). The AP-1 factors have also been shown to interact with other nuclear proteins which may modify their target specificity and transcriptional activity (Hai and Curran, 1991; Schüle and Evans, 1991). This constitutes an operative basis for a large diversity of the transcriptional control, which allows a flexible and precise regulation of the expression of a specific subset of genes in response to extracellular stimuli.

The adrenal medulla responds to stimulation exerted by preganglionic sympathetic nerve terminals by secretion of catecholamines and costored bioactive peptides to meet the adaptive changes needed. ACh is the major transmitter in preganglionic nerve terminals, and it binds to nicotinic receptors on chromaffin cells to elicit secretion (Ungar and Philips, 1983). This activation is followed by selective long-term induction of genc cxpression. Transsynaptic regulation of catecholamine synthesizing enzymes 
(Axelrod, 1971; Thoenen, 1975; Zigmond, 1985) and more recently coexisting peptides has been studied by several research groups (LaGamma et al., 1989; Stachowiak and Goc, 1992; Wan et al., 1992; Dagerlind et al., 1994). Some results in these studies have been controversial, especially those dealing with the regulation of preproenkephalin (ENK) mRNA levels. Thus, decreased impulse activity after denervation and explanting the adrenal medulla increase ENK peptide (Schultzberg et al., 1979; Bohn et al., 1983; LaGamma et al., 1984; Dagerlin et al., 1994) and mRNA levels (Kilpatrick et al., 1984; LaGamma et al., 1985, 1989; Dagerlind et al., 1994). Other researchers have demonstrated an increase in ENK mRNA and peptide levels after direct and reflex stimulation of the adrenal medulla (Kanamatsu et al., 1986; Stachowiak and Goc, 1992).

AP-1 binding sites are present in several of the enzyme and peptide genes expressed in adrenal chromaffin cells, and it has been suggested that AP-1 binding proteins play an important role in the regulation of adrenal gene expression (Stachowiak et al., 1990a,b; Gog et al., 1992; Icard-Liepkalns et al., 1992; Stachowiak and Goc, 1992). Levels of c-fos, c-jun, and junB mRNAs and proteins are normally low or undetectable in the adrenal medulla, whereas a high expression of c-jun mRNA is seen in the adrenal cortex (Koistinaho, 1991; Koistinaho et al., 1993; Pelto-Huikko et al., 1991; Pennypacker et al., 1992; Wessel and Joh, 1992). Stimulation of adrenal chromaffin cells in vivo or in vitro with nicotine or angiotensin (Stachowiak et al., 1990a,b; Koistinaho, 1991; Koistinaho et al., 1993) and reflex activation of splanchnic nerve with reserpine, insulin or capsaicin induce c-fos and c-jun mRNAs and proteins in the adrenal medulla (Stachowiak et al., 1990a,b; Pelto-Huikko et al., 1991; Wessel and Joh, 1992). On the other hand, Pennypacker et al. (1992) suggested that high levels of AP-1 binding activity are present in normal adrenal medulla and that nicotine treatment decreases AP-1 binding activity without any detectable changes in the levels of AP-1 proteins. They suggested that DNA binding in rat adrenal gland is controlled at the posttranslational level, possibly through dephoshorylation.

Since the studies dealing with the regulation of ncuropeptides in the adrenal medulla are partially controversial, and since various treatments can affect the same gene and the same treatment can influence genes differentially, we examined changes in expression of IEGs in adrenal medulla in response to a variety of experimental manipulations. Thus, the neuronal mechanisms underlying the induction of $c-f o s, c-j u n$, and junB IEGs in the adrenal medulla were analyzed using immunohistochemistry, Northern blotting, and in situ hybridization. The changes in AP-1 DNA binding activity were studied using electrophoresis mobility shift assay.

\section{Materials and Methods}

Experimental animals. Adult male Sprague-Dawley rats (2-3 months of age) were used for this study (University of Tampere, Department of Biomedical Sciences, Tampere, Finland, or ALAB Laboratories, Stockholm, Sweden). The animals were maintained on a 12:12 hr light-dark schedule (light $0700-1900$ ), at $22-23^{\circ} \mathrm{C}$ room temperature, and at 60 $65 \%$ relative humidity. All experimental treatments were accepted by the local ethical committees for animal research. At least five animals were included for each time point studied. Nontreated and saline in jected animals were used as controls. Five groups of animals were processed for in situ hybridization.

The first set of animals (group 1;n=30) received a single subcutaneous injection of capsaicin ( $25 \mathrm{mg} / \mathrm{kg}$; Sigma, St. Louis, MO) dissolved in $10 \%$ Tween-80 and $10 \%$ ethanol in physiological saline. Rats were decapitated $30 \mathrm{~min}, 1,2,3$, and $6 \mathrm{hr}$ after the treatment.
Rats in group $2(n=10)$ were anesthetized with chloral hydrate, and the left adrenal gland was surgically denervated. After 4 weeks, five of them received an injection of capsaicin $(25 \mathrm{mg} / \mathrm{kg}$, s.c.) $30 \mathrm{~min}$ before decapitation.

Group 3 rats $(n=40)$ were injected intraperitoneally with nicotine ( $2 \mathrm{mg} / \mathrm{kg}$, Sigma), and the rats were decapitated after 5, 10, 20,30 min, and 1,2 , and $6 \mathrm{hr}$.

Group $4(n=35)$ received an injection of muscarine $(0.1 \mathrm{mg} / \mathrm{kg}$, i.p.; Sigma) $10,20,30 \mathrm{~min}$, and 1, 2, and $6 \mathrm{hr}$ before decapitation.

Group 5 animals $(n-40)$ were given an intraperitoneal injection of chlorisondamine ( $5 \mathrm{mg} / \mathrm{kg}$, Ciba-Geigy), atropine $(1 \mathrm{mg} / \mathrm{kg}$; Leiras, Helsinki, Finland), or a combination of chlorisondamine and atropine $1 \mathrm{hr}$ before injection with capsaicin $(25 \mathrm{mg} / \mathrm{kg}$, s.c.). They were sacrificed $30 \mathrm{~min}$ after the capsaicin injection.

After excision the adrenals were placed in ice-cold saline. All adrenals from each group were mounted together with controls on the same chuck and frozen on dry ice. Cryostat sections ( $14 \mu \mathrm{m}$ thick) were cut in a Microm HM 500 cryostat (Heidelberg, Germany) and thawed onto Probe-On (Fischer Scientific, Pittsburgh, PA) or Super Frost (Menzel, Germany) glasses and stored at $-20^{\circ} \mathrm{C}$ until used.

For immunocytochemical demonstration of the respective proteins rats $(n=30)$ were injected with capsaicin $(25 \mathrm{mg} / \mathrm{kg}$, s.c.) $1,2,4$, and $6 \mathrm{hr}$ before sacrifice. Nicotine ( $2 \mathrm{mg} / \mathrm{kg}$, i.p.) and muscarine $(0.1 \mathrm{mg} / \mathrm{kg}$, i.p.) were given 1 and $2 \mathrm{hr}$ before perfusion. The rats were anesthesized with an overdose of chloral hydrate and perfused transcardially first with $100 \mathrm{ml}$ of physiological saline followed by $2 \%$ paraformaldehyde in phosphate-buffered saline (PBS) for $5 \mathrm{~min}$. The adrenals were excised and postfixed in the same fixative for $1 \mathrm{hr}$. The tissues were cryoprotected with $10 \%$ sucrose in PBS, frozen with carbon dioxide gas, and sectioned at $14 \mu \mathrm{m}$. The sections were thawn onto chromgelatin-subbed glass slides and processed directly for immunocytochemistry.

For Northern blotting and electrophoresis mobility shift assay rats ( $n$ $=10$ ) were injected intraperitoneally with $2 \mathrm{mg} / \mathrm{kg}$ nicotine and sacrificed $30 \mathrm{~min}$ and $2 \mathrm{hr}$ after the injection, respectively.

Hybridization probes. Oligonucleotide probes were obtained from Scandinavian Gene Synthesis (Köping, Sweden). The probe sequences were complementary to nucleotides corresponding to amino acids 137 152 and 235-250 of rat c-fos (Curran et al., 1987), amino acids 265280 of mouse c-jun (Ryseck et al., 1988), amino acids 195-210 of mouse junB (Ryder et al., 1988), and nucleotides 595-642 of rat phenylethanolamine $N$-methyltransferase (PNMT) mRNA (Weisberg et al., 1989; Mezey, 1989). All nucleotides were labeled to a specific activity of 5-25 $\times 10^{8} \mathrm{cpm} / \mu \mathrm{g}$ at the $3^{\prime}$ end using terminal deoxynucleotidyltransferase (Amersham International, Amersham, Buckingshamshire, UK) and ${ }^{35}$ S-dATP (NEN, Boston, MA). Several control probes with the same length, similar GC-content and specific activity were used to ascertain the specificity of the hybridizations. Addition of a 100 times excess of respective unlabeled probe abolished all hybridization signals.

In situ hybridization. In situ hybridization was carried out as previously described (Dagerlind et al., 1992). The slides were incubated in humidified boxes at $4^{\circ} \mathrm{C}$ for $18 \mathrm{hr}$ with $1 \times 10^{\circ} \mathrm{cpm}$ of the labeled probe in a hybridization mixture containing $50 \%$ of formamide (G.T. Baker Chemicals B W, Deventer, Holland $), 4 \times$ SSC $(1 \times \mathrm{SSC}=0.15$ $\mathrm{M} \mathrm{NaCl}$ and $0.015 \mathrm{M}$ sodium citrate), $1 \times$ Denhardt $(0.02 \%$ bovine serum albumin, $0.02 \%$ Ficoll, $0.02 \%$ polyvinylpyrrolidone), $1 \%$ sarkosyl ( $N$-laurylsarcosine; Sigma), $0.02 \mathrm{M}$ sodium phosphate $(\mathrm{pH} 7.0), 10 \%$ dextran sulfate (Pharmacia, Uppsala, Sweden), $500 \mu \mathrm{g} / \mathrm{ml}$ salmon testis DNA (Sigma), and $200 \mathrm{~mm}$ dithiothreitol (LKB, Bromma, Sweden). Sections were subsequently rinsed in $1 \times \mathrm{SSC}$ at $55^{\circ} \mathrm{C}$ for $60 \mathrm{~min}$ with four changes of SSC and finally in $1 \times$ SSC starting at $55^{\circ} \mathrm{C}$ and slowly cooled to room temperature (about $\mathbf{l} \mathrm{hr}$ ), transferred through distilled water, and briefly dehydrated in 60 and $95 \%$ ethanol for $30 \mathrm{sec}$ each, air dried, and covered with Amersham $\beta$-max autoradiography film (Amersham) for 5-15 d. Films were then developed with LX 24 developer (Kodak, Rochester, NY) for $2 \mathrm{~min}$ and fixed with Unifix (Agfa Gaevert, Leverkusen, Germany) for $15 \mathrm{~min}$. Subsequently, the sections were dipped in Kodak NTB2 nuclear track emulsion (diluted 1:1 with distilled water). After exposure for $20-40 \mathrm{~d}$ at $-20^{\circ} \mathrm{C}$, the sections were developed with D 19 (Kodak) for 2 min and fixed in G 333 (Agfa) for 4 min and examined in a Nikon Microphot-FX microscope equipped with a dark-field condenser. T-Max 100 black-and-white film (Kodak) was used for photography. Finally, the sections were stained with cresyl violet and analyzed under bright-field conditions.

Image analysis. The measurements were performed on a Macintosh IIx (Apple Computer Inc., Cupertino, CA) equipped with a Quick Cap- 
ture frame grabber board (Data Translation, Marlboro, MA), a Northern Light precision illuminator (Imaging Research, St. Catharines, Ontario, Canada) and a DAGE-MTI CCD-72 series camera (DAGE-MTI, Michigan City, IN) equipped with a Nikon $55 \mathrm{~mm}$ lens. To process images, the IMAGE software (courtesy of Dr. Wayne Rusband, NIMH, Bethesda, MD) was used. Each frame was digitized to a $512 \times 512$ matrix with 256 gray levels for cach picture element. To adjust for possible defects in the illumination or optical pathway, an image of the empty illumination screen was taken through a neutral filter and used for background shading correction. The gray levels corresponding to the ${ }^{14} \mathrm{C}$-plastic standards (Amersham; see Miller, 1991) lying within the exposure range of the film were determined and used in a third degree polynomial approximation to construct a gray level to activity transfer function. The borders of the measuring fields were interactively defined, and the average activity in the tissues was calculated using the Macintosh computer (Apple) and wINGz software (Informix Software, Lenexa, KA). Graphs were made with CRICKET GRAPH software, and the relative changes in mRNA levels were expressed as percentage of control.

Statistics. Statistical analyses of the treatments were performed using the Student's $t$ test with a Bonferroni correction of the significance levels using BMDP statistical software (BMDP Statistical Software Inc., Los Angeles, CA). At least four sections from each animal $(n=5)$ were measured and the mean value was used in statistical analysis.

Antibodies. A rabbit polyclonal antiserum generated against amino acids 128-152 of the rat Fos (Young et al., 1991) was generously donated by Dr. Michael Iadarola (NIH, Bethesda, MA). The Jun (607/6) and JunB (725/5) antibodies were raised in rabbits against amino acids 80-334 and 46-344, respectively (Herdegen et al., 1991; Kovary and Bravo, 1991). The rabbit antisera to PNMT were purchased from Eugene Technics International (Allendale, NJ) and Incstar Co. (Stillwater, $\mathrm{MN}$ ). The specificity of these antisera has been established, and they have been used in several published studies.

Immunocytochemistry. Fos, Jun, and JunB were demonstrated using the ABC-method (Vectastain Elite kit; Vector Laboratories, Burlingame, CA). The antibodies were diluted with PBS containing $0.3 \%$ Triton $\mathrm{X}-100$ and $1 \%$ bovine serum albumin. The dilutions were 1:5000-1: 10,000 for Fos and 1:2000-1:4000 for Jun and JunB. The sections were incubated for $12-18 \mathrm{hr}$ at $4^{\circ} \mathrm{C}$, and after several washes incubated at room temperature with biotinylated goat anti-rabbit antibody $(1: 200)$ and $\mathrm{ABC}$-complex for $30 \mathrm{~min}$ each. The immunoreactions were visualized with $0.02 \%$ diaminobenzidine and $0.02 \%$ hydrogen peroxide. For localization of IEGs in the adrenaline cells the sections were subsequently incubated overnight with the two rabbit antisera raised against the adrenaline synthesizing enzyme PNMT. Both antibodies were used at a dilution 1:500. After washes the sections were incubated with FITClabeled goat anti-rabbit secondary antibody (1:100; Boehringer Mannheim Scandinavia, Stockholm, Sweden). The sections were embedded in a mixture of glycerol and PBS containing $0.1 \%$ para-phenylenediamine (Johnson and de Araujo-Nogueira 1981) and photographed with a Nikon Microphot FXA microscope equipped with appropriate filters for light and fluorescence microscopy.

Northern blot analysis. Frozen adrenal glands (approximately $400 \mathrm{mg}$ from controls or from rats injected with $2 \mathrm{mg} / \mathrm{kg}$ nicotine i.p. $25 \mathrm{~min}$ before decapitation) were placed in $4 \mathrm{M}$ guanidine isotiocyanate (GITC) (USB, Cleveland, OH), $0.1 \mathrm{M} \beta$-mercaptoethanol, $0.025 \mathrm{M}$ sodium citrate $(\mathrm{pH} 7.0)$ and immediately homogenized with a Polytrone (Kineunatica, Swilzerland). Each tissue homogenate was layered over a $4 \mathrm{ml}$ cushion of $5.7 \mathrm{M} \mathrm{CsCl}$ in $0.025 \mathrm{M}$ sodium citrate $(\mathrm{pH} 5.5)$ and centrifuged at $20^{\circ} \mathrm{C}$ in a Beckman SW41 rotor at $35,000 \mathrm{rpm}$ for $18 \mathrm{hr}$. The recovery of total RNA was quantified spectrophotometrically at $260 \mathrm{~nm}$ and $15 \mu \mathrm{g}$ of total RNA from each sample was separated on a $1 \%$ agarose gel containing $0.7 \%$ paraformaldehyde, blotted onto Hybond- $\mathrm{N}$ membranes (Amersham), and cross-linked by UV illumination. Membranes were prehybridized at $42^{\circ} \mathrm{C}$ for $4-6 \mathrm{hr}$ in a solution containing $50 \%$ formamide (J.T. Baker), $5 \times$ SSPE $(1 \times \mathrm{SSPE}=0.15 \mathrm{~m}$ sodium chloride, $0.01 \mathrm{M}$ sodium dihydrogen phosphate monohydrate, $0.001 \mathrm{M}$ EDTA), $0.1 \%$ sodium dodecyl sulfate (SDS), $2 \times$ Denhardt's $(0.02 \%$ each of polyvinylpyrrolidone, Sigma; Ficoll, Sigma; bovine scrum albumin, USB), and $200 \mu \mathrm{g} / \mathrm{ml}$ of sheared and heat denatured salmon testis DNA (Sigma). Eight nanograms of ${ }^{32} \mathrm{P}$-labeled $\left(2-4 \times 10^{9}\right.$ $\mathrm{cpm} / \mu \mathrm{g}$ ) oligonucleotide probe per milliliter of hybridization solution was added, and the incubation was continued for an additional 18-20 hr at $42^{\circ} \mathrm{C}$. Membranes were washed in $2 \times$ SSPE and $0.1 \%$ SDS $(2$ $\times 10 \mathrm{~min}$ at $\left.55^{\circ} \mathrm{C}\right), 1 \times \mathrm{SSPE}$ and $0.1 \%$ SDS $\left(1 \times 20 \mathrm{~min}\right.$ at $\left.55^{\circ} \mathrm{C}\right)$, and $0.1 \times$ SSPE and $0.1 \%$ SDS $(2 \times 10 \mathrm{~min}$ at room temperature $)$ and exposed to film (Reflection, NEN) with intensifying screens (Reflection, NEN) at $4^{\circ} \mathrm{C}$ for $12-24 \mathrm{hr}$.

Electrophoresis mobility shift assay. Whole adrenal glands of control animals $(n=4)$ and rats $(n=4)$ injected intraperitoneally with $2 \mathrm{mg} / \mathrm{kg}$ nicotine $2 \mathrm{hr}$ before decapitation were homogenized in hypotonic buffer ( $10 \mathrm{~mm}$ HEPES, $1.5 \mathrm{mM} \mathrm{MgCl}_{2}, 10 \mathrm{~mm} \mathrm{KCl}, \mathrm{pH} \mathrm{7.9)}$ incubated on ice, centrifuged, and the pellet was resuspended in high salt buffer $(20 \mathrm{~mm}$ HEPES, 25\% glycerol, $1.5 \mathrm{~mm} \mathrm{MgCl}_{2}, 1.2 \mathrm{M} \mathrm{KCl}, 0.2 \mathrm{~mm}$ EDTA, $\mathrm{pH}$ 7.9). Subsequently, low salt buffer ( $20 \mathrm{~mm}$ HEPES, $25 \%$ glycerol, 1.5 $\mathrm{mM} \mathrm{MgCl}_{2}, 20 \mathrm{mM} \mathrm{KCl}, \mathrm{pH} 7.9$ ) was added dropwise to the solution. All solutions contained $0.5 \mathrm{~mm}$ DTT and $0.2 \mathrm{~mm}$ PMSF added freshly from stock solutions. After incubating the mixture for $30 \mathrm{~min}$ on ice, the samples were centrifuged at $25000 \times g$ and the supernatant was aliquoted for storage at $-80^{\circ} \mathrm{C}$. The protein concentration was measured using the Iowry method for protein quantification To further control the amount and quality of the protein extracts, the samples were electrophoresed through $12 \%$ SDS-polyacrylamide gel and stained with Coomassie blue.

Synthetic oligomer containing consensus AP-1 binding site (5'CGCTTGATGAGTCAGCCGGAA- $3^{\prime}$ and the corresponding complementary DNA sequence) was labeled at the 5'-end with $\tau-{ }^{32}$ PdATP using T4 polynucleotide kinase and purified from uncorporated isotope with Nensorb column (NEN). Equal amounts of nuclear extracts from both nicotine treated and control animals $(10 \mu \mathrm{g})$ were used for DNAbinding assays. Binding reactions $(20 \mu \mathrm{l})$ were performed at room temperature for $20 \mathrm{~min}$ in a mixture containing $10 \mathrm{mM}$ Tris- $\mathrm{HCl}(\mathrm{pH} 7.5)$, $4 \%$ glycerol, $1.0 \mathrm{~mm} \mathrm{MgCl}, 50 \mathrm{~mm} \mathrm{NaCl}, 0.5 \mathrm{~mm}$ EDTA, $1.0 \mathrm{~mm}$ DTT, $1 \mu \mathrm{g}$ poly [d (I-C)], and 20,000 cpm (approximately $0.16 \mathrm{ng}$ ) of the probe. Protein-DNA complexes were separated through $4 \%$ nondenaturing polyacrylamide gel. Gels were run at $100 \mathrm{~V}$ in Tris-glycine buffer ( $\mathrm{pH} 8.5$ ), dried, and exposed to Kodak XAR autoradiograph film. To characterize the composition of AP-1 protein complex the DNA binding mixture was incubated with Fos antibody (dil. 1:200) for 30 $\mathrm{min}$ at room temperature before addition of the probe.

\section{Results}

\section{In situ hybridization}

Control animals. In control (nontreated or saline injected) animals low levels of $\mathrm{c}-f o s, \mathrm{c}-j u n$, and $j u n \mathrm{~B}$ mRNAs were present in the adrenal medulla (Fig. $1 a-c$ ). In the adrenal cortex high expression of c-jur mRNA was observed (Fig. 1b). Low and moderate levels were seen after long exposure with probes to c-fos and jun $\mathrm{B}$, respectively (data not shown). In the following description of IEG mRNAs will refer to adrenal medulla unless elsewise stated.

Capsaicin treatment (group 1). Single subcutaneous injection of capsaicin caused a rapid increase in the expression of all three IEGs (Fig. 1). The induction was fastest for c-fos mRNA which reached the peak value (38.2-fold increase, $P \leq 0.001)$ in 30 min. Thereafter, the mRNA values declined to control levels in $6 \mathrm{hr}$. The c-jun (4.2-fold increase, $P \leq 0.001$ ) and jun B (12.7fold increase, $P \leq 0.001$ ) mRNAs reached the highest levels slower with the maximum at $1 \mathrm{hr}$. The levels returned to those of control animals in $6 \mathrm{hr}$ (Fig. 2).

When the distribution of the mRNAs for the IEGs were compared to that of the adrenaline synthesizing enzyme PNMT, the most intense induction of c-fos and c-jun mRNAs was observed in the adrenaline cells with lower levels in the noradenaline cells (PNMT mRNA-negative). junB mRNA was localized mainly to the adrenaline cells (Fig. $3 a-f$ ).

Denervation and capsaicin treatment (group 2). After 4 weeks of denervation the medullary IEG mRNA levels in the denervated (left) adrenals did not differ from those of the control animals. In the intact (right) medulla the levels were slightly elevated when compared to the controls, especially for c-fos (3.3-fold increase, $P \leq 0.01$ ). Denervation almost completely blocked the increases induced by capsaicin when compared to 

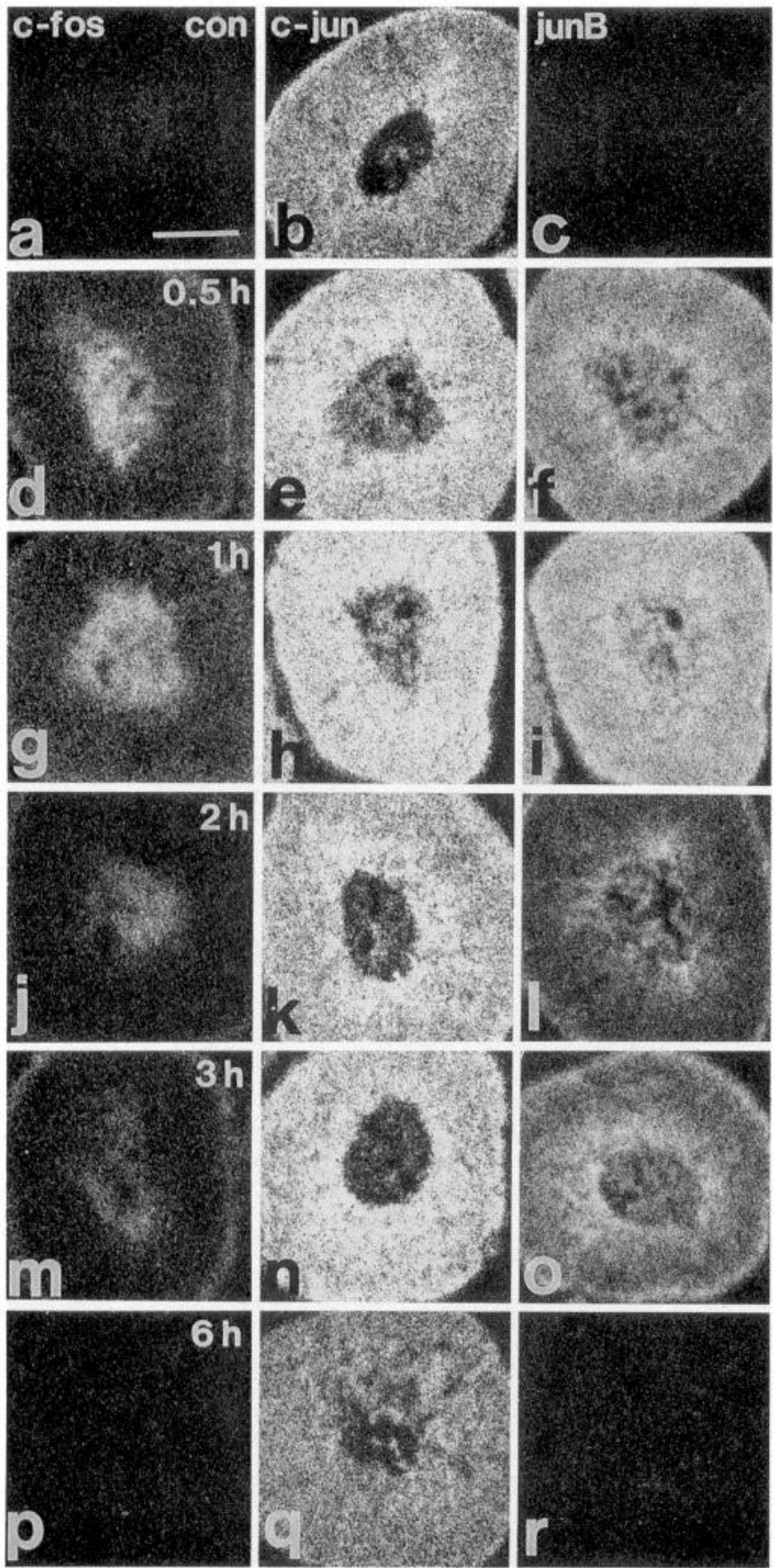

Figure 1. $a-r$, Film autoradiographs of rat adrenal glands of controls $(a-c)$ and at different times $(30 \mathrm{~min}, d-f ; 1 \mathrm{hr}, g-i ; 2 \mathrm{hr}, j-l ; 3 \mathrm{hr}, m-$ $o ; 6 \mathrm{hr}, p-r)$ after a single capsaicin injection and hybridization with probes to mRNA for c-fos $(a, d, g, j, m, p)$, c-jun $(b, e, h, k, n, q)$, and jun B $(c, f, i, l, o, r)$. The levels of c-fos $(a), c-j u n(b)$, and jun B mRNA (c) are low in the adrenal medulla of control rats. High levels of c-jun mRNA are seen in the adrenal cortex in the control $(b)$. Increased mRNA levels are seen in the adrenal medulla with all three probes after $30 \mathrm{~min}$, and the induction lasts for $3 \mathrm{hr}$ and returns to control levels after $6 \mathrm{hr}$. Note increased expression of all three mRNAs also in the adrenal cortex $(d-o)$. Scale bar, $1 \mathrm{~mm}$ for $a-r$.

the intact side, only jun B mRNA levels increased 2.8 -fold $(P \leq$ 0.05 ) in the denervated adrenal medulla (Figs. $4 a-y, 5$ ).

Nicotine treatment (group 3). Nicotine caused a very rapid (within $5 \mathrm{~min}$ ) induction of all mRNAs studied in the medulla. c-fos and c-jun mRNAs peaked at $20 \mathrm{~min}$ (36.7- and 8-fold

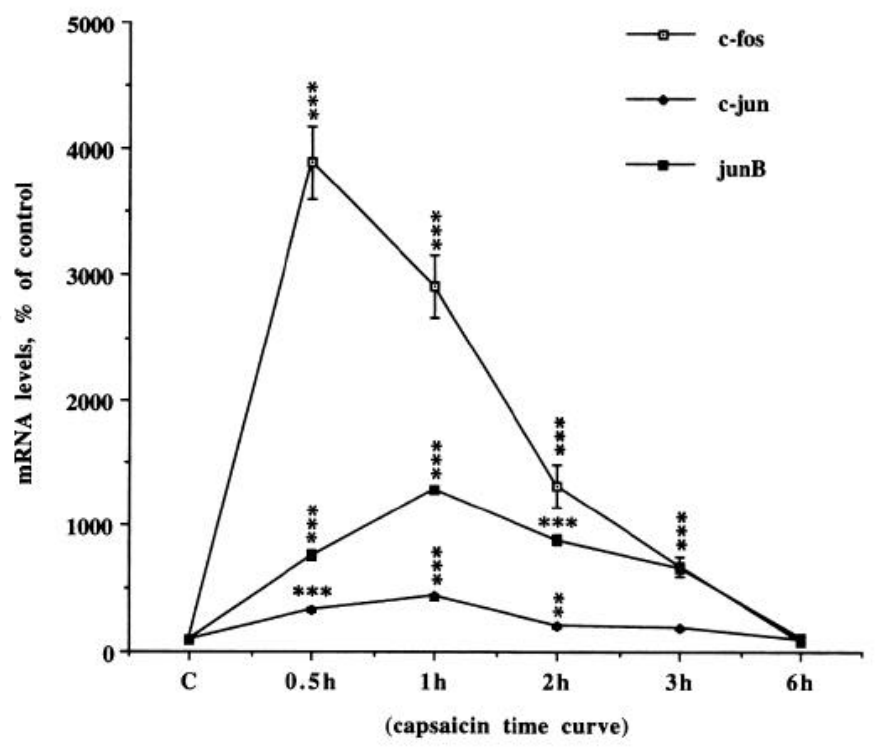

Figure 2. Quantitative results of the experiments shown in Figure 1 using computerized image analysis. c-fos mRNA is markedly increased, peaking at $30 \mathrm{~min}$. There is also a pronounced increase in jun B mRNA levels. Note that the increase even in c-jun mRNA values is 4.2 -fold. Values represent the mean \pm SEM from five animals. ${ }^{* * *}, P \leq 0.001$; $* *, P \leq 0.01$.

increases, respectively, $P \leq 0.001$ for both) and junB reached the maximum level at $30-60 \mathrm{~min}$ (38.8-fold increase, $P \leq$ 0.001). c-fos mRNA levels subsided below control levels at 6 $\mathrm{hr}$, whereas c-jun and jun B mRNAs were still slightly elevated at this point (Fig. 6).

Muscarine treatment (group 4). Muscarine injection caused less dramatic changes in the mRNA levels. However, inductions were observed already after $10 \mathrm{~min}$ and c-fos mRNA reached the highest level at $20 \mathrm{~min}$ (3.1-fold increase, $P \leq 0.001)$ and c-jun and jun B mRNAs at 30 min (1.6- and 5.6-fold increases, respectively, $P \leq 0.01$ and $P \leq 0.001$, respectively). The levels of c-fos and c-jun mRNAs returned to control values in $1 \mathrm{hr}$, and in $2 \mathrm{hr}$ for junB; thereafter, they declined below those seen in controls (Fig. 7).

Treatment with capsaicin plus receptor antagonists (group 5). Treatment of the animals with chlorisondamine or atropine alone caused a slight decrease in the levels of c-fos mRNA. Combination of chlorisondamine and atropine caused a 8.6-fold increase in the levels of c-fos mRNA $(P \leq 0.001)$. Chlorisondamine caused a reduction in the capsaicin induced increase in c-fos mRNA levels (28.9- vs 8.9-fold increases, $P \leq 0.001$ ), and the combination of chlorisondamine and atropine was equally effective (down to a 7.4-fold increase, $P \leq 0.001$ ), whereas atropine alone had a moderate effect (down to a 23.4-fold increase, $P \leq 0.001$ ). c-jun and jun B mRNAs were both marginally affected by chlorisondamine and atropine alone, whereas the combination caused an increase in the mRNA levels (1.8and 8.9-fold increases, respectively, $P \leq 0.05$ and $P \leq 0.001$, respectively). Neither chlorisondamine, nor atropine nor the combination affected the increase in c-jun mRNA values after capsaicin. Chlorisondamine and atropine had no effect on jun B mRNA, whereas the combination potentiated the effect of capsaicin (19.4- vs 15.3-fold increases, $P<0.01$ ) (Figs. 8, 9).

\section{Immunocytochemistry}

Only few immunoreactive nuclei were observed in the adrenal medulla of control or saline injected animals when stained with 

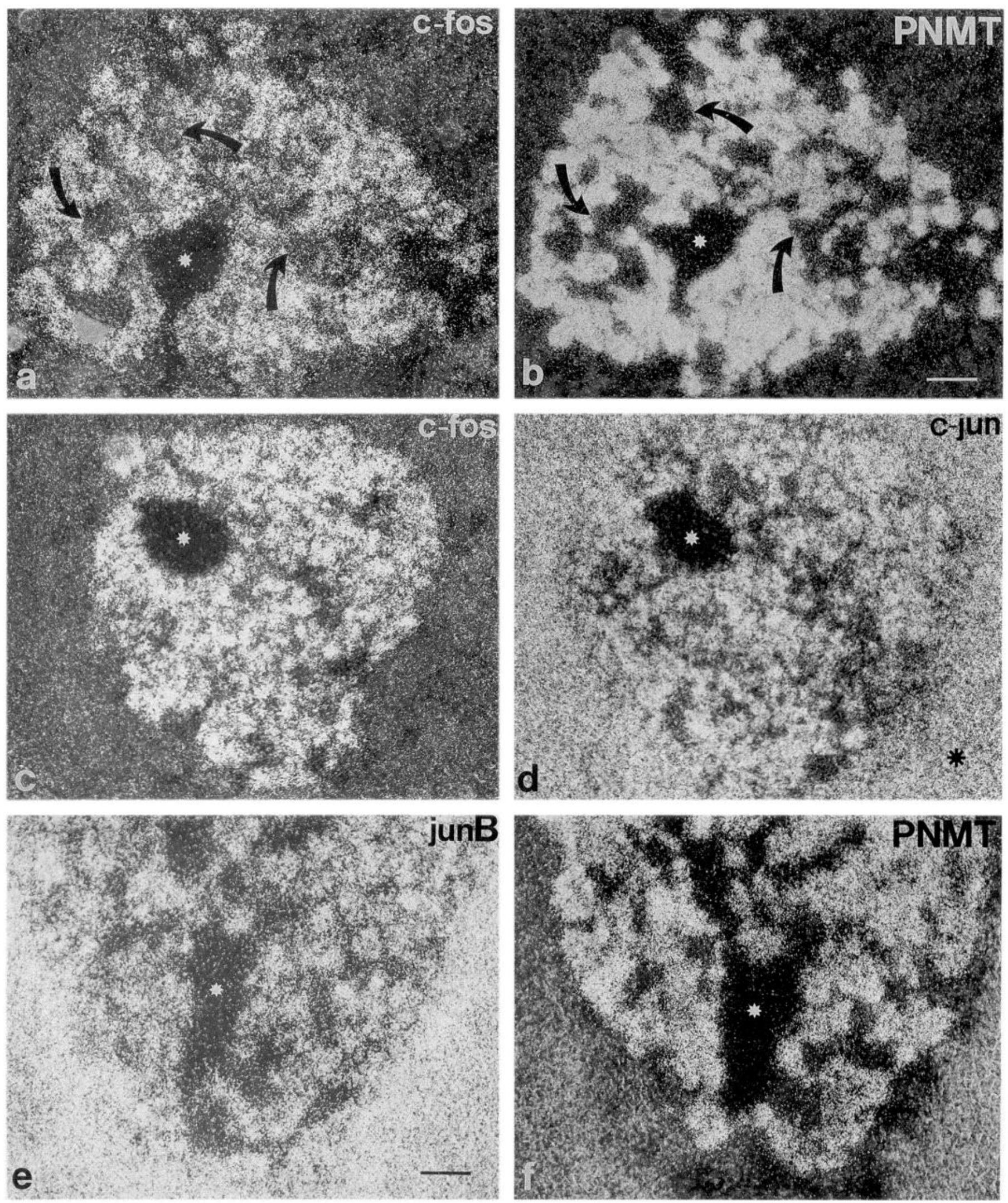

Figure 3. $a-f$, Emulsion autoradiographs of rat adrenal glands $30 \mathrm{~min}(a, b, e, f)$ and $1 \mathrm{hr}(c, d)$ after capsaicin treatment and hybridization with probes to mRNA for c-fos $(a, c)$, PNMT $(b, f), c-j u n(d)$, and junB $(e) . a$ and $b, c$ and $d$, as well as $e$ and $f$ show, respectively, consecutive sections. $a$ and $b$, c-fos labeling is heterogeneous in the adrenal medulla, and the labelling of the adrenaline (PNMT-containing) cells is strong. However, only a weak signal is seen over the noradrenaline (PNMT-negative) cells (curved arrows). $c$ and $d$, The distribution of c-jun mRNA is heterogeneous $(d)$ and similar to that of c-fos. Note strong signal for c-jun mRNA in the cortex (asterisk in $d$ ). $e$ and $f$, The distribution of junB mRNA is heterogeneous and appears mainly in PNMT-labeled areas (cf. $e$ with $f$ ). Stars indicate blood vessels. Scale bars: $b 50 \mu \mathrm{m}(a-d) ; e, 30 \mu \mathrm{m}(e, f)$ ). 


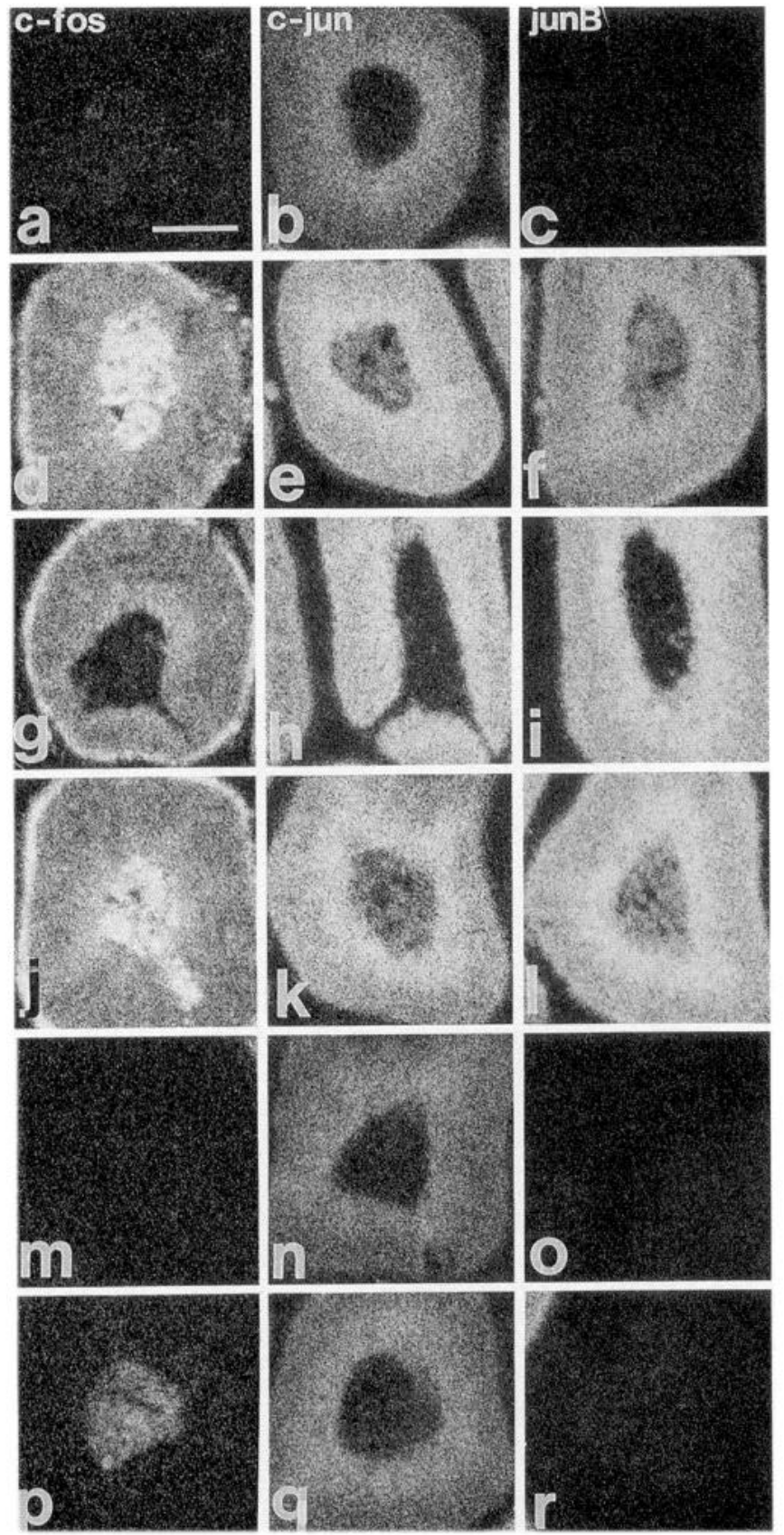

Figure 4. $a-r$, Film autoradiographs of rat adrenal glands of controls $(a-c)$ and after treatment with capsaicin $(d-f)$, capsaicin plus denervation (ipsilateral side) $(g-i)$, capsaicin plus denervation (contralateral side) $(j-l)$, denervation (ipsilateral side) $(m-o)$, and denervation (contralateral side) $(p-r)$ after hybridization with probes to mRNA for c-fos $(a, d, g, j, m, p), \mathrm{c}-j u n(b, e, h, k, n, q)$, or junB $(c, f, i, l, o, r)$. Note strong upregulation in cortex for all three IEG mRNAs after capsaicin $(d-f, j-l)$ which is not blocked by denervation $(g-i)$. There is also an increase in c-fos mRNA levels in the medulla contralateral to unilateral denervation $(p)$. Scale bar, $1 \mathrm{~mm}$ for $a-r)$.

Figure 5. $a-c$, Quantitative results showing mRNA for c-fos $(a)$, c-jun $(b)$, and jun $\mathrm{B}(c)$, taken from the experiments shown in Figure 4 using computerized image analysis. There is a marked increase in all three IEG mRNAs after capsaicin treatment, but only the c-fos increase is completely blocked by denervation. Note increase in c-fos mRNA levels on the contralateral side of rats subjected to unilateral denervation. Values represent the mean \pm SEM from five animals.
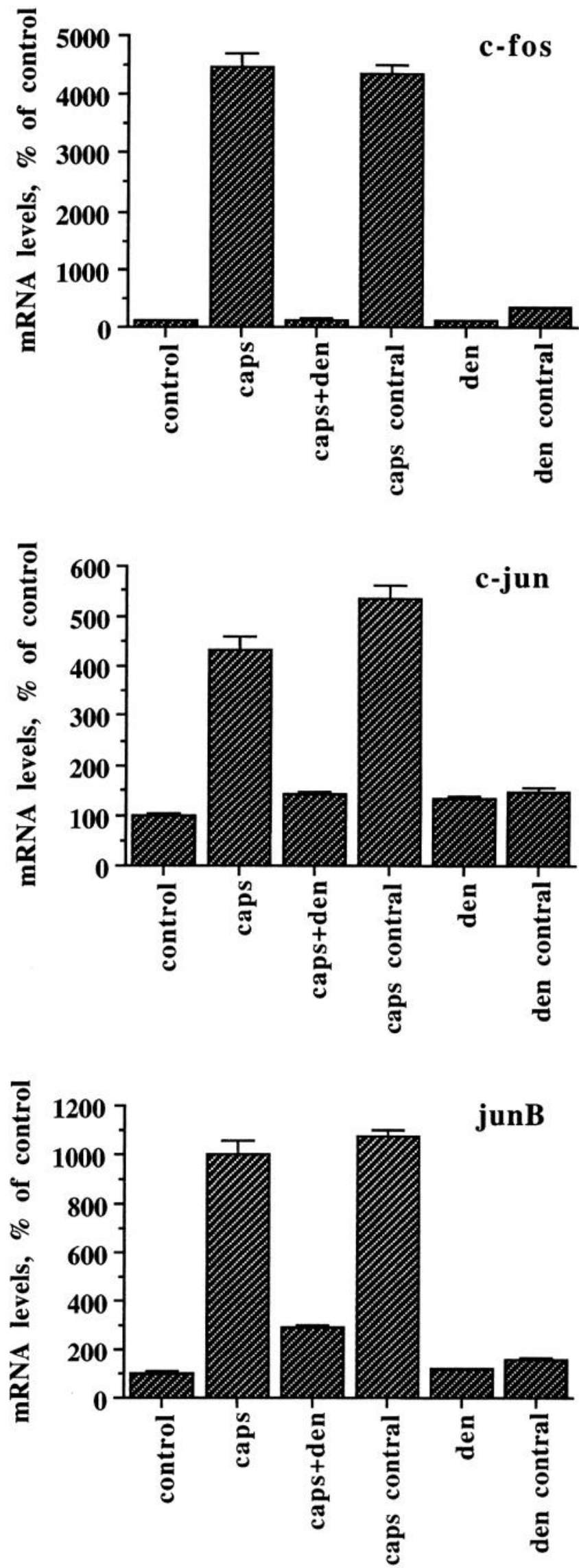


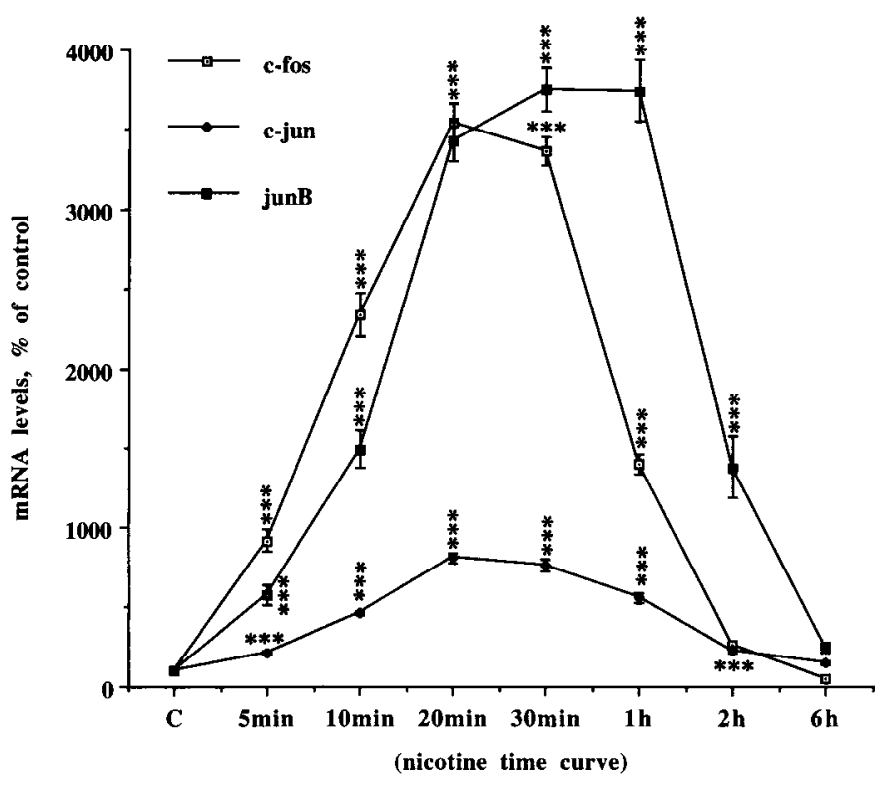

Figure 6. Quantitative results showing the effect of nicotine on IEG mRNA expression in rat adrenal medulla using computerized image analysis. Note that the increase in c-fos and junB mRNA levels after nicotine treatment is much stronger than for $\mathrm{c}-j u n$. Values represent the mean \pm SEM from five animals. ***, $P \leq 0.001$.

antibodies to Fos, Jun and JunB. Some labeled nuclei were seen in the zona fasciculata and reticulata of adrenal cortex of control rats with all three antibodies (Fig. 10a,d,g).

After capsaicin treatment most of the nuclei in the adrenal medulla were labeled with antibodies to Fos at 1,2 (Fig. 10b), and $4 \mathrm{hr}$ after injection. Only few nuclei were labeled at $6 \mathrm{hr}$. Also after nicotine injection most cells were intensely stained (Fig. 11a), whereas after muscarine treatment the staining was lighter with only a small percentage of the cells stained (Fig. $11 e$ ). The staining was heterogenous after all treatments, and double labeling with antibodies to PNMT showed that labeling for Fos-like immunoreactivity (LI) was more intense in adrenaline cells than in noradrenaline cells after all treatments (Figs. $10 b, c ; 11 a, b, g, h)$.

Jun-LI was also induced in most of the cells in adrenal medulla at 1, 2 (Fig. 10e), and $4 \mathrm{hr}$ after capsaicin treatment, and the labeling had disappeared at 6 hr. Nicotine induced Jun-LI in most of the nuclei, whereas after muscarine only few cells were labeled in the adrenal medulla (Fig. 11c,i). Double labeling with PNMT showed that adrenaline cells exhibited a stronger staining than noradrenaline cells after these treatments (Figs. 10e,f; $11 c, d, i, j)$.

JunB-LI was observed in about half of the cells after 1, 2 (Fig. 10h), and $4 \mathrm{hr}$ of capsaicin treatment, and only few cells were labeled at $6 \mathrm{hr}$. Nicotine induced JunB-LI in equal number of cells as capsaicin, while after muscarine injections few cells were labeled (Fig. 11e,k). Most of the JunB-immunoreactive cells were adrenaline cells after all treatments and only single noradrenaline cells were labeled (Figs. 10h,i;11e,f,k,l).

Increased staining for all three IEGs was seen in the adrenal cortex after the treatments used (to be published elsewhere).

\section{Northern hybridization}

Northern analysis using the same oligonucleotide probes as used for in situ hybridization revealed mRNAs of expected size ver-

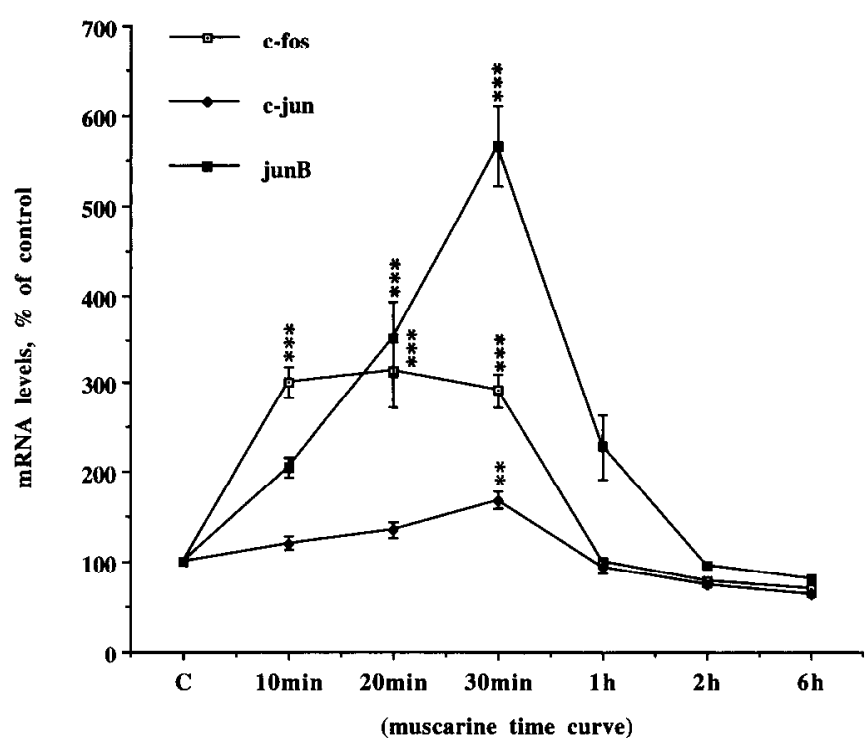

Figure 7. Quantitative results showing the effect of muscarine on IEG mRNA expression in rat adrenal medulla using computerized image analysis. Values represent the mean \pm SEM from five animals. ${ }^{* * *}, P$ $\leq 0.001 ; * *, P \leq 0.01$.

ifying the specificity of the probes utilized (Fig. 12). The hybridization signal for c-fos was very low in non-treated rats, whereas after nicotine injection a clear increase in the intensity was observed. Levels of $j u n \mathrm{~B}$ were readily detectable in control animals, and there was an apparent rise in junB mRNA levels in nicotine treated rats. Levels of c-jun mRNA were high in the controls, and they were further increased by nicotine stimulation (Fig. 12).

\section{Electrophoresis mobility shift assay}

The AP-1 DNA binding activity was low in the whole adrenals of control animals (Fig. 13). Two hours after single nicotine injection a marked increase in AP-1 binding activity could be seen (Fig. 13). The binding reaction could be totally blocked by addition of 100 molar excess of unlaheled AP-1 oligonucleotide. Preincubation of the reaction mixture with antibody to Fos caused a further reduction in the mobility of the AP-1/protein complex in control animals. In nicotine injected animals part of the AP-1/protein complex supershifted, whereas the majority of the complex migrated to the original position (Fig. 13).

\section{Discussion}

Basal and stimulated expression of $c$-fos, $c$-jun, and jun $B$ in the adrenal gland

In this study the levels of c-fos, c-jun, and jun B mRNAs were low in the adrenal medulla of nontreated animals, and only a few, weakly labeled nuclei were seen in the medulla with antibodies to the respective proteins. Northern blot analysis showed that the level of c-fos mRNA in whole adrenal gland is low which is in accordance with the results obtained with in situ hybridization. The levels of junB and c-jun mRNAs were moderate and high, respectively, which reflects their expression in the adrenal cortex. In previous studies the mRNA levels reported for $\mathrm{c}-f o s, \mathrm{c}-j u n$, and jun $\mathrm{B}$ in the adrenal medulla of nontreated animals have been low (Stachowiak et al., 1990a,b; Pelto-Huikko et al., 1991; Wessel and Joh, 1992; Koistinaho et al., 1993) and also the number of labeled nuclei with antibodies to Fos 


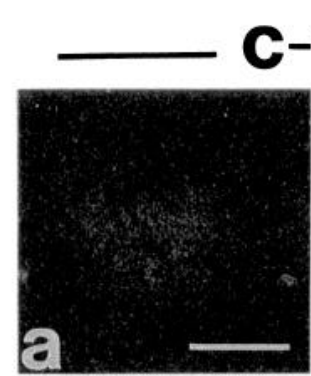

\section{fos}
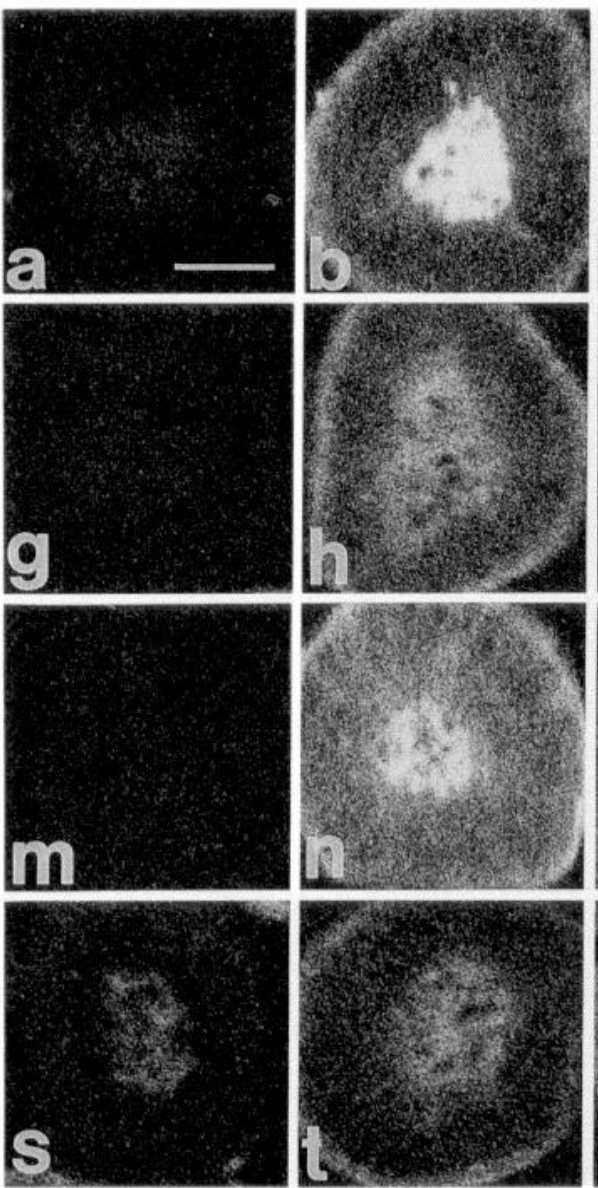
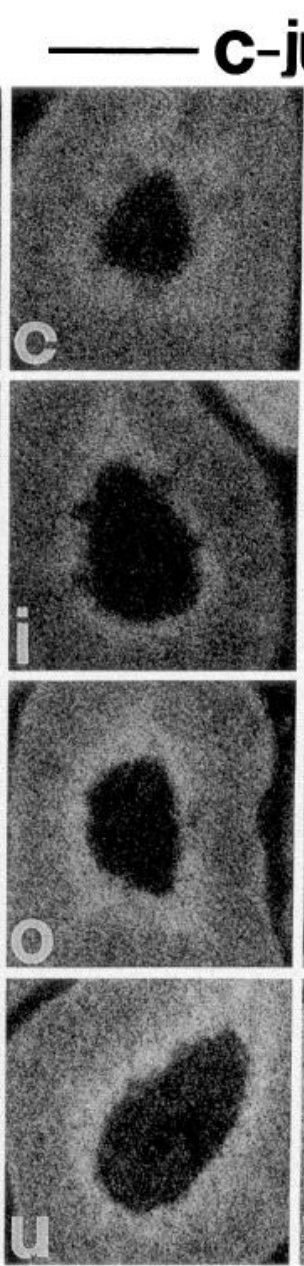

jun
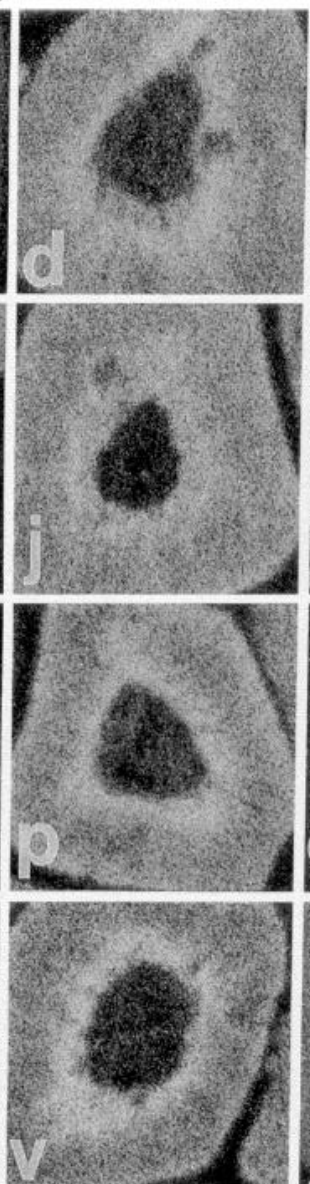

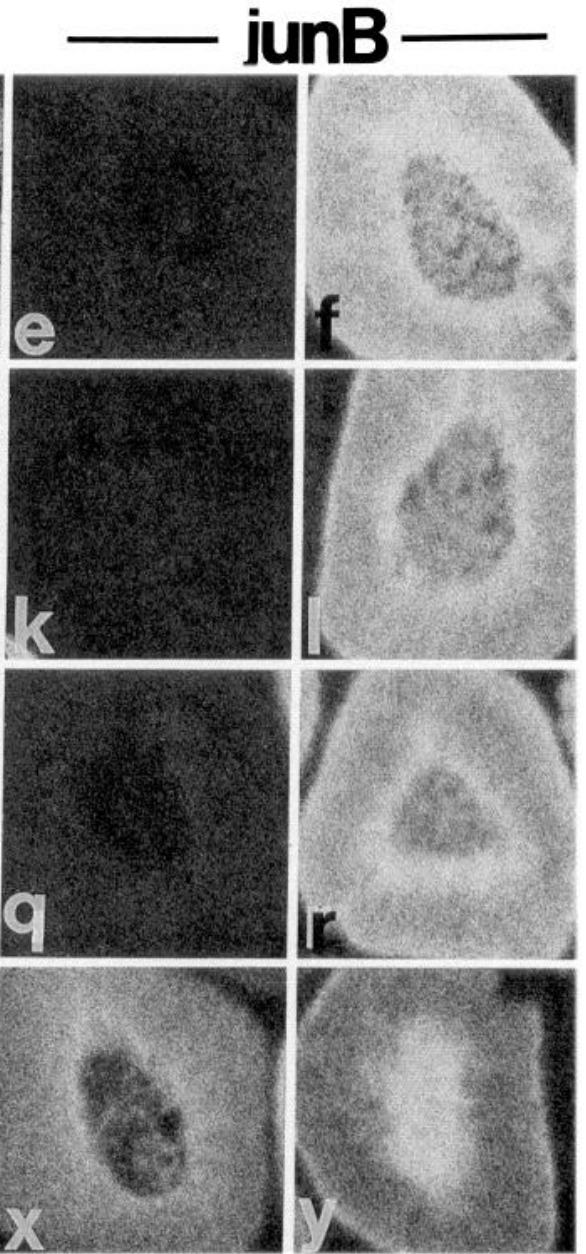

Figure 8. $a-y$, Film autoradiographs of rat adrenal gland of controls $(a, c, e)$ and after treatment with capsaicin $(b, d, f)$, chlorisondamine $(g, i$, $k)$, chlorisondamine plus capsaicin $(h, j, l)$, atropine $(m, o, q)$, atropine plus capsaicin $(n, p, r)$, chlorisondamine and atropine $(s, u, x)$, or chlorisondamine and atropine plus capsaicin $(t, v, y)$ after hybridization with probes to mRNA for c-fos $(a, b, g, h, m, n, s, t)$, c-jun (c, d, $i, j, o, p, u$, $v)$, or $j u n \mathrm{~B}(e, f, k, l, q, r, x, y)$. A strong capsaicin induced elevation is seen after $30 \mathrm{~min}$ for $\mathrm{c}-f o s(b)$ and $j u n \mathrm{~B}(f)$ mRNA. Chlorisondamine treatment attenuates capsaicin-induced elevation of c-fos mRNA $(h)$ without affecting the increases in $j u n \mathrm{~B}$ (1) mRNA. Note only small effect of atropine on the capsaicin-induced increase $(m-r)$. The combination of chlorisondamine and atropine increases the levels of c-fos $(s)$, c-jun $(u)$, and especially junB $(x)$ mRNAs in the adrenal medulla. This combination of antagonists attenuates the capsaicin-induced increase in c-fos $(t)$ mRNA without affecting the increase in c-jun mRNA $(v)$, but increases the capsaicin-induced elevation in junB mRNA levels $(y)$. Scale bar, $100 \mu \mathrm{m}$ for $a-y$.

was negligible (Koistinaho, 1991; Wessel and Joh, 1992). Western blot analyses of adrenal medullary extracts and cultured bovine chromaffin cells have, on the other hand, shown that different size Fos, Fos-related antigens (Fras), and Jun proteins are present (Stachowiak et al., 1990a,b; Pennypacker et al., 1992). The differences may be due to sensitivies of the methods used.

Pennypacker et al. (1992) proposed that both adrenal cortex and medulla contain equivalent levels of Fras and c-jun protein; however, the majority of AP-1 binding activity was localized to the medulla. They did not observe any changes in the levels of AP-1 binding proteins after acute nicotine treatment, and in addition they reported decreased levels of AP-1 binding activity in the medulla after this treatment. They concluded that in the adrenal medulla AP-1 binding activity is controlled at a posttranslational level and not by increased expression of AP-1 proteins. These results are in contrast to our findings that in nontreated rats mRNA levels for $\mathrm{c}-$ fos, c-jun, and jun B are higher in adrenal cortex, and that nuclear immunoreactivity for these proteins are only seen in the adrenal cortex. In addition we found a marked induction of $\mathrm{c}-f o s, \mathrm{c}-j u n$, and $j u n \mathrm{~B}$ mRNAs and proteins in adrenal medulla and cortex after several treatments including nicotine injection. Also the other members of the fos-family (fra$1, f r a-2$, and fos $\mathrm{B}$ ) and jun $\mathrm{D}$ seem to share the same pattern of localization and regulation (Pelto-Huikko and Dagerlind, unpublished observations). We also found that AP-1 DNA binding activity in control adrenals was low and a single nicotine injection caused a marked increase in AP-1 activity. The AP-1 binding activity seen in controls is probably due to the expression of AP-1 binding proteins in adrenal cortex. In control adrenals preincubation of the AP-1/protein complex with Fos antibody caused a formation of one supershifted band suggesting that majority of the AP-1 binding complexes are in the form of Fos/Jun dimers. In nicotine treated animals only a portion of the AP-1 binding activity supershifted demonstrating that dimeric complexes lacking Fos are present in stimulated adrenal glands. Our results strongly implicate that also in adrenal medulla (Stachowiak et al., 1990a; Icard-Liebkalns et al., 1992; Stachowiak and Goc, 1992), as in most tissues (Sonnenberg et al., 1989a; Mor- 


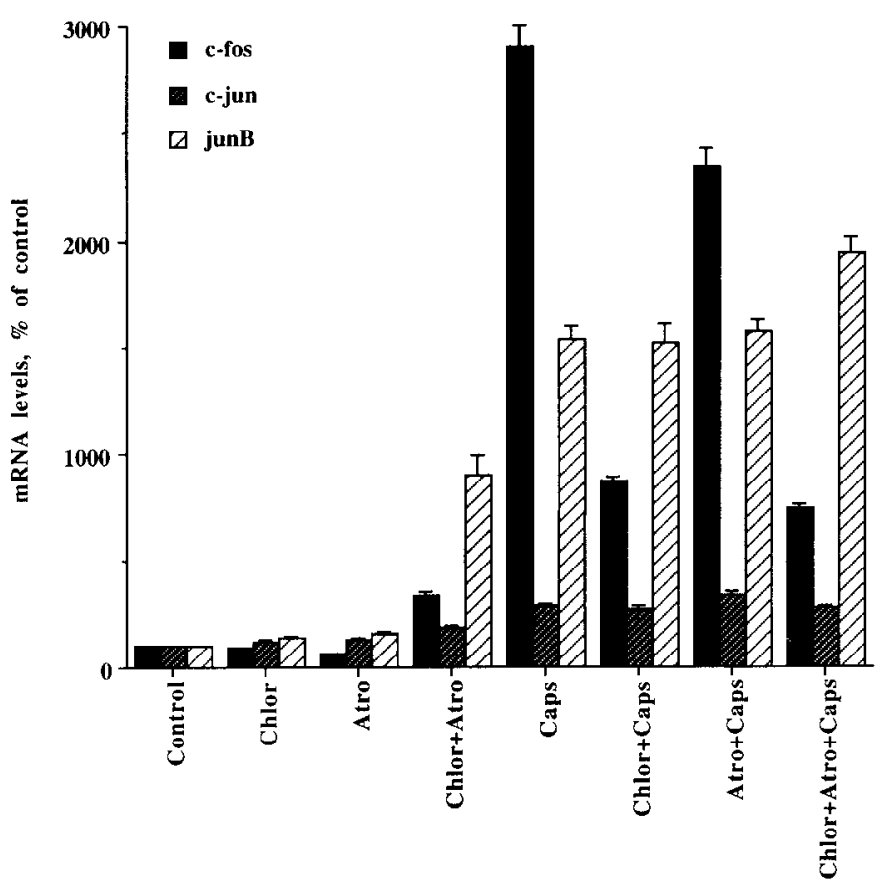

Figure 9. Quantitative results of the experiments shown in Figure 8 using computerized image analysis. Values represent the mean \pm SEM from five animals.

gan and Curran, 1991), the level of AP-1 binding activity is regulated by increased expression of AP-1 binding proteins.

\section{Preferential induction of IEGs in adrenaline cells}

Wessel and Joh (1992) have reported a patchy distribution of c-fos and c-jun mRNAs in the adrenal medulla after reserpine treatment. Also the distribution of Fos-LI described in previous reports was heterogenous after nicotine and reserpine injections (Koistinaho, 1991; Wessel and Joh, 1992). Here we show with comparative in situ hybridization studies and with double labeling immunocytochemistry that capsaicin and nicotine treatments induce c-fos and c-jun mRNAs and proteins preferentially in adrenaline cells. The selective induction also of junB mRNA and protein in adrenaline cells reported here has not been described previously.

One may speculate that the treatments used stimulate adrenaline cells more intensely than noradrenaline cells and that this would explain the stronger induction seen in the former cells. This seems less likely, since after the same treatments other IEGs are induced only in noradrenaline cells (Pelto-Huikko et al., unpublished observations). Thus, our findings suggest that the IEGs studied here are more important in regulating the gene expression in adrenaline cells than in noradrenaline cells and that distinct differences exist between these two cells types in their signal transduction pathways.

The members of the Fos family cannot form homodimers or heterodimers with each other, whereas Jun proteins are capable of forming homodimers and heterodimers with each other and with the Fos proteins (Sheng and Greenberg, 1990; Angel and Karin, 1991; Morgan and Curran, 1991; Ryseck and Bravo, 1991). JunB has been reported to preferentially form heterodimers with other AP-1 proteins based on differences in its DNAbinding and dimerization motif (Deng and Karin, 1993). When Fos proteins are present they will, due to their incapability to dimerize with each other, drive the balance towards the formation of heterodimers (O'Shea et al., 1989, 1992).

The mobility shift assay demonstrates that most of the AP-1 binding complexes in control animals are Fos/Jun dimers, whereas after nicotine treatment larger proportion of the binding activity is build up by dimers lacking Fos. Our findings suggest that the preferential dimer formed in noradrenaline cells is Fos/Jun, whereas in adrenaline cells Fos/JunB, Fos/Jun, Jun/Jun, and JunB/Jun dimers are major AP-1 factors. Since c-fos, c-jun, and junB mRNAs and proteins exhibited almost similar time courses of induction, it is uncertain whether or not temporal changes in the composition of AP-1 complexes occurred. However, since the other members of the fos family and junD are also induced in the adrenal medulla (unpublished observations), detailed studies of their distribution and of the magnitude and time course of their induction are needed to further define the composition of the dimers formed in different cell types.

The various homo-/heterodimers of AP-1 proteins differ in their affinities to the AP-1 binding sites and in their ability to activate gene transcription (Sheng and Greenberg, 1990; Morgan and Curran, 1991; Ryseck and Bravo, 1991). Fos and Jun proteins have also been shown to interact with other nuclear proteins like the ATF/CREB transcription factors (Hai and Curran, 1991) and the members of the steroid receptor superfamily (Schule and Evans, 1991). This could allow flexible and precise regulation of target genes in different types of chromaffin cells after various types of stimuli.

\section{Neurotransmitters regulating IEG expression in adrenal medulla}

$\mathrm{ACh}$ is the main transmitter released from splanchnic nerve terminals to activate chromaffin cells (see Ungar and Philips, 1983). Both nicotinic and muscarinic cholinergic receptors are present in rat adrenal medulla. Of the several muscarinic receptor subtypes cloned (Bonner et al., 1987), mRNAs for the m3 and $\mathrm{m} 4$ receptors are found in rat adrenal medulla (Fernando et al., 1991). However their distribution in different cell types has not yet been defined. It is not known which subtypes of nicotinic receptors are expressed in adrenal medulla (Deneris et al., 1991).

In the rat adrenal medulla $\mathrm{ACh}$ from splanchnic nerve ter-

Figure 10. $a-i$, Immunocytochemical demonstration of Fos- $(a, b)$, Jun- $(d, e)$, JunB- $(g, h)$, and PNMT $(c, f, i)$-LIs is in the rat adrenal medulla of control rat $(a, d, g)$ and $2 \mathrm{hr}$ after capsaicin treatment $(b, c, e, f, h, i)$ rats. Arrowheads in $a$ indicate border between cortex and medulla. No staining is seen in the adrenal medulla of control rats with antibodies to Fos $(a)$, Jun $(d)$, and JunB $(g)$. Labeled nuclei can be seen in the zona reticulata of adrenal cortex with all antibodies $(a, d, g)$. Almost all chromaffin cells exhibit nuclear Fos-LI after capsaicin treatment $(b)$, whereas the ganglion cells (curved arrows) remain unstained. In the same section cells showing lighter Fos staining (arrow) correspond to noradrenaline (PNMT-negative) cells $(c)$. Most of the chromaffin cell nuclei are stained with antibodies to Jun after capsaicin treatment, and the ganglion cell nuclei (curved arrow) are lightly stained (e). Double staining with antibodies to PNMT shows that the cells exhibiting lighter labeling (arrows) in $e$ are noradrenaline cells $(f)$. Most of the adrenaline cells contain JunB-LI after capsaicin treatment $(h, i)$, whereas staining in noradrenaline cells is weak (arrows). Scale bars, $50 \mu \mathrm{m}(a, d, g$ and $b, d, e, f, h, i$ have the same magnifications, respectively). 

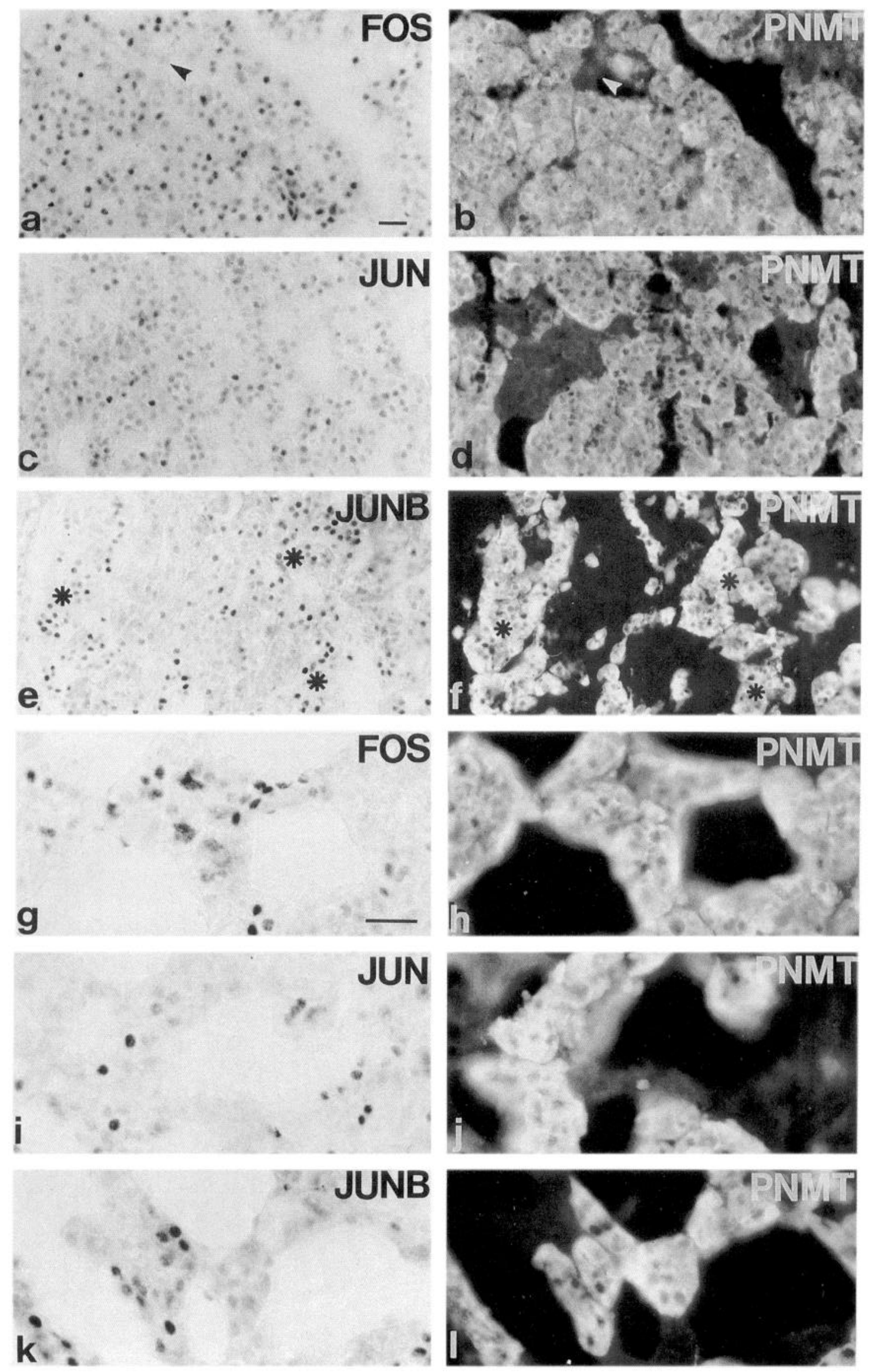


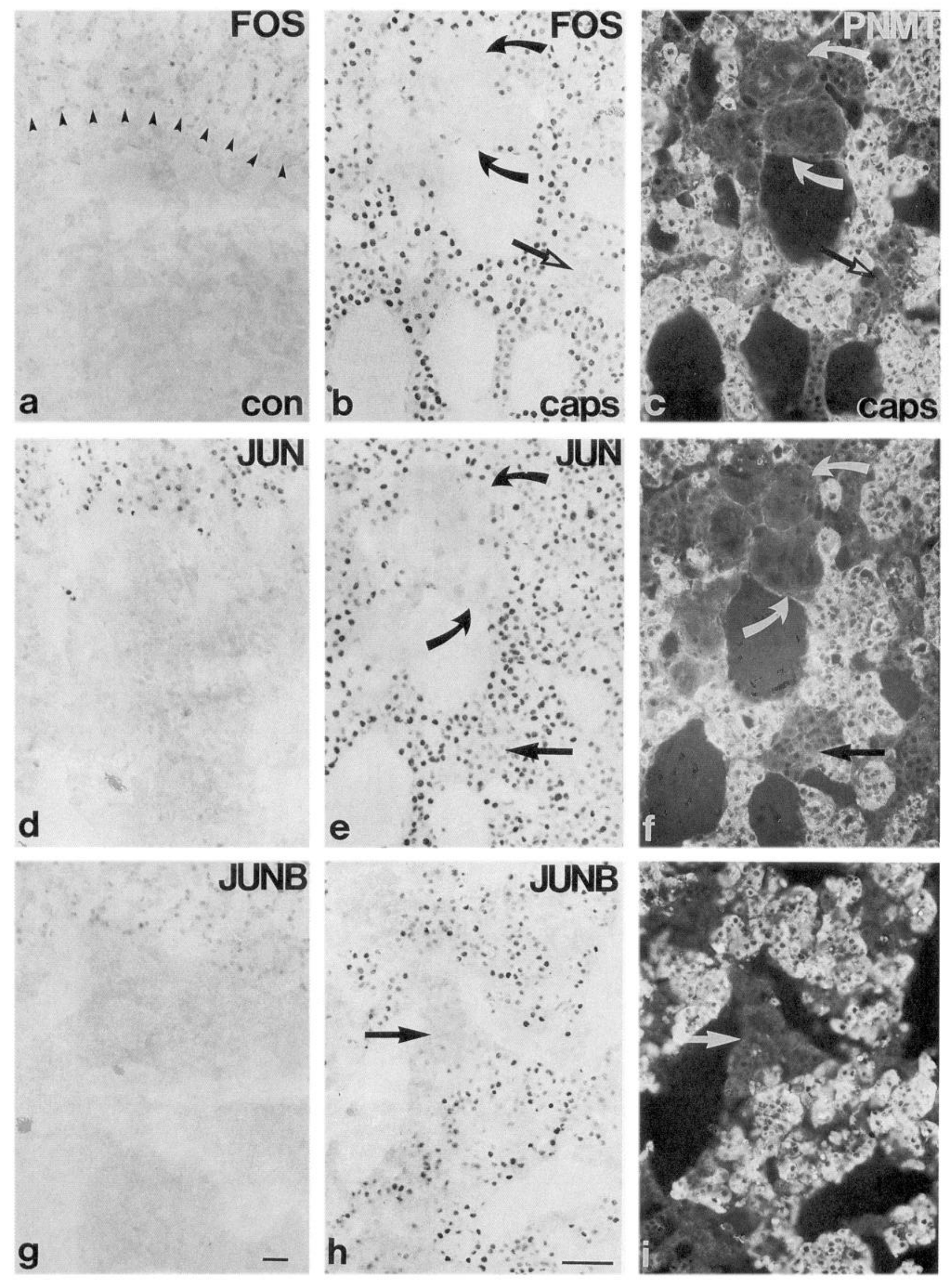


minals releases both adrenaline and noradrenaline. Muscarinic receptor antagonists do not have any significant effect on the secretion of adrenaline and noradrenaline, whereas nicotinic receptor antagonists completely block the secretion of both catecholamines (Warashina et al., 1989). Nicotinic agonist release both catecholamines, whereas muscarinic agonist selectively release adrenaline (Warashina et al., 1989), an observation which has also been reported for the cat adrenal medulla (Douglas and Poisner, 1965). These findings suggest that either muscarinic receptors are located only on adrenaline cells or that muscarinic receptors on noradrenaline cells are not coupled to the secretion process. The finding that secretion evoked by endogenous $\mathrm{ACh}$ is not affected by muscarinic antagonists has lead to the suggestion that muscarinic receptors are not located in the synaptic cleft but occur in the extrajunctional region (Warashina et al., 1989).

Nicotine was the most potent inducer of expression of IEGs, and previous studies have shown that nicotinic agonists induce c-fos, c-jun, and jun B mRNAs in PC-12 cells (Greenberg et al., 1986; Bartel et al., 1989) and also in cultured bovine chromaffin cells (Stachowiak et al., 1990b). In vivo nicotine has been shown to induce Fos-LI in the nuclei of rat adrenal medullary cells (Koistinaho, 1991). Our findings demonstrate that treatment of rats with nicotine can activate expression of IEGs in the rat adrenal medulla. Whether the induction of c-jun and jun $\mathrm{B} \mathrm{m}-$ RNAs in fact is mediated by nicotinic receptors can not be answered definitely, since the capsaicin-induced elevation of these mRNAs could not be blocked by chlorisondamine and/or atropine (see below). The findings that capsaicin-induced elevation of c-fos mRNA was clearly reduced by chlorisondamine and to a lesser extent by atropine suggest that $\mathrm{ACh}$ acting on nicotinic cholinergic receptor may be the major regulator of c-fos expression in adrenal medulla in our paradigm.

All the IEGs studied have been reported to be induced by muscarinic agonists in different cell lines (Greenberg et al., 1986; Trejo et al., 1992); however, in the present study muscarine treatment increased the mRNA levels only slightly when compared to nicotine and capsaicin treatments. This suggests that, although activation of muscarinic receptors can affect IEG expression in chromaffin cells, these receptors are not the main mediator of $\mathrm{ACh}$ induced IEG expression in the rat adrenal medulla. This is also supported by the finding that atropine was able to reduce c-fos induction after capsaicin, but did not affect c-jun and jun B inductions. Moreover, chlorisondamine was clearly more effective in blocking c-fos induction after capsaicin, and this effect was not significantly potentiated by atropine. As the muscarinic receptors on adrenaline cells conceivably are not situated at synaptic cleft (Warashina et al., 1989), ACh may be able to bind the muscarinic receptors only after diffusion from the synapse. The effect of atropine on the capsaicin-induced elevation of c-fos mRNA may thus be due to an indirect effect of

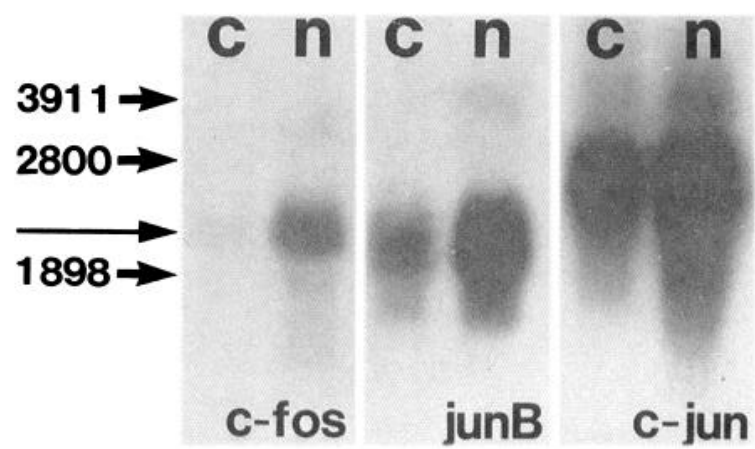

Figure 12. Northern analysis of total RNA extracts of whole adrenal from controls $(c)$ and after 25 min of nicotine treatment $(n)$ using probes against c-fos, c-jun, and jun B mRNAs. Low levels of $2.2 \mathrm{~kb}$ c-fos mRNA is seen in control adrenal gland (long arrow), and an increase in the mRNA levels is seen after nicotine treatment. Moderate level of $2.1 \mathrm{~kb}$ jun $\mathrm{B}$ mRNA is present in the control adrenal and levels are elevated by nicotine treatment. High levels of $2.6 \mathrm{~kb}$ c-jun mRNA are seen in control adrenals which is further increased by nicotine treatment. The probes used are the same as used for the in situ hybridization experiments; 3911,2800 , and 1898 indicate size and migration of the RNA size markers used

atropine resulting in decreased secretion of $\mathrm{ACh}$ or another transmitter regulating c-fos expression.

There is substantial evidence for a noncholinergic transmission in sympathetic ganglia and adrenal medulla. Fossom et al. (1991a) found that stimulation of adrenal medulla with nicotine produced a clear induction of tyrosine hydroxylase (TH) expression, and this induction could only be partially blocked with the nicotine receptor antagonists hexamethonium and mecamylamine. In denervated adrenal gland the induction of $\mathrm{TH}$ by nicotine was completely prevented by the antagonists (Fossom et al., 1991b). They suggested that nicotine activates CNS pathways resulting in stimulation of splanchnic nerve and subsequent release of $\mathrm{ACh}$ and other neurotransmitters that interact with receptors other than the nicotinic cholinergic receptor. In agreement, Schalling et al. (1991) showed that denervation, but not chlorisondamine completely blocked the reserpine-induced increase in adrenal TH mRNA levels. In sympathetic ganglia TH activity is increased after nerve stimulation even in the presence of hexamethonium and atropine, which suggests that a noncholinergic transmitter is released from the preganglionic nerve terminals (Ip et al., 1983). Baruchin et al. (1993) demonstrated that the cold stress-induced increase in PNMT mRNA levels could not be inhibited by chlorisondamine or atropine.

We have used capsaicin to reflex-stimulate the splanchnic nerve terminals in the adrenal medulla (Holzer, 1988; Watanabe et al., 1988). Capsaicin causes a noxious stimulus resulting in a general stress response, and in addition it releases neuropeptides from primary sensory neurons (Jancso et al., 1977; Holzer,

$\leftarrow$

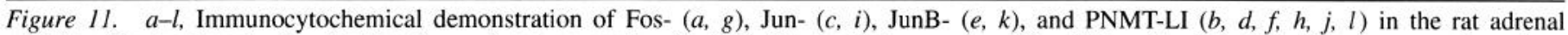

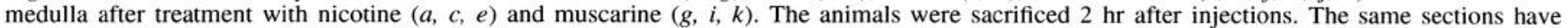

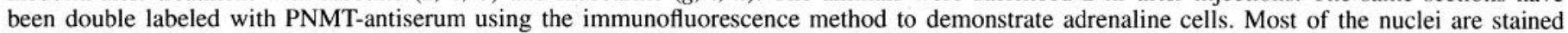

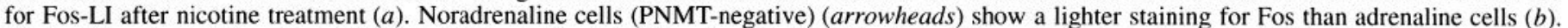

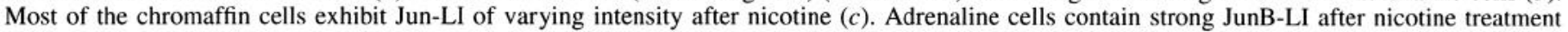

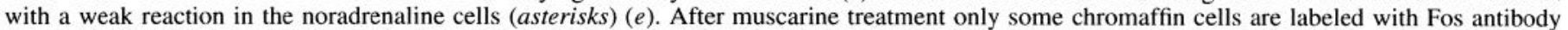

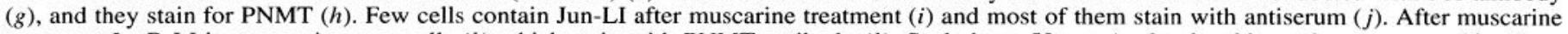

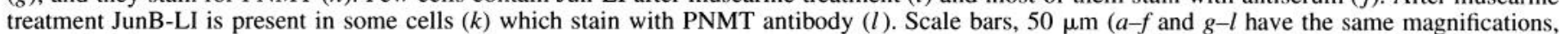
respectively). 


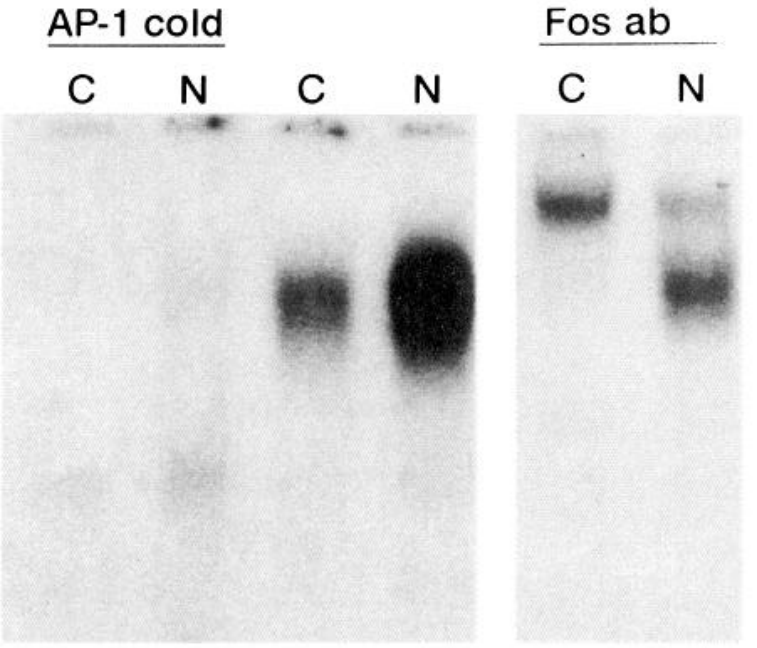

Figure 13. Electrophoresis mobility shift assay of control (c) and after $2 \mathrm{hr}$ of nicotine treatment $(n)$ with AP-1 oligomer. Low level of AP-1 DNA binding activity is seen in control adrenals, whereas strong binding can be seen after nicotine treatment. Addition of 100 -fold excess nonlabelled AP-1 oligomer (AP-1 cold) totally displaces the binding. Preincubation of the reaction mixture with an antibody to Fos causes a reduction in the mobility of the AP-1/protein complex in control animals. In nicotine injected animals part of the AP-1/protein complex is supershifted, whereas the majority of the complex migrates to the original position.

1988). The present denervation experiments showed that capsaicin does not have a direct effect on chromaffin cells. The slight increase seen in jun B mRNA levels in denervated adrenal gland after capsaicin treatment may be due to circulating factors such as glucocorticoids which are increased after capsaicin treatment (Lembeck and Amann, 1986; Amann and Lembeck, 1987).

Also our results with nicotinic and muscarinic receptor antagonists and capsaicin suggest that there is a noncholinergic component involved in regulating the expression of all IEGs studied. The effect of capsaicin on c-jun and jun B could not be blocked cholinergic antagonists, and in addition the combination of chlorisondamine and atropine potentiated the effect of capsaicin on jun $\mathrm{B}$ expression. Furthermore, the combination of antagonists stimulated IEG expression, and it may be speculated that this occurs in response to reflex activation of the splanchnic nerve and subsequent release of a noncholinergic transmitter.

In addition to ACh there are several other possible transmitters in splanchnic nerve terminals which may mediate the effects on IEG expression in the adrenal medulla after reflex stimulation. Most of the preganglionic neurons in the spinal cord contain nitric oxide synthase (NOS) (Blottner et al., 1993). NOS produces nitric oxide (NO) which has been shown to act as a neurotransmitter in several regions of the nervous system (Bredt and Snyder, 1992; Moncada, 1992). Thus NO is a potential messenger regulating IEG expression. In fact, in a recent report (Haby et al., 1994) it has been shown that stimulation of the cGMP pathway by NO induces the expression of c-fos and junB, but not of c-jun and jun $\mathrm{D}$ indicating a selective activation of IEGs by NO via cGMP. The most abundant peptidergic preganglionic nerve terminals so far observed in rat adrenal medulla contain enkephalins (Schultzberg et al., 1978; Pelto-Huikko, 1989), and most of them also co-store ACh (Kondo et al., 1985). Different opiate receptors subtypes are present in adrenal medulla (Chavkin et al., 1987; Bunn et al., 1988); thus, enkephalins may act as neurotransmitters in adrenal medulla. Since capsaicin also releases neuropeptides, for example, substance P, galanin, and calcitonin gene-related peptide, from primary sensory terminals (Jancso et al., 1977; Holzer, 1988) present in the adrenal medulla (Pelto-Huikko and Salminen, 1987; Pelto-Huikko, 1989) these peptides may partially account for IEG induction after capsaicin treatment.

\section{Possible target genes for IEGs in adrenal medulla}

The preproENK and TH genes contain a functional AP-1 site or a related sequence in their promotor regions (Sonnenberg et al., 1989b; Gizang-Ginsberg and Ziff, 1990; Icard-Liebkalns, 1992), suggesting that they may be targets for AP-1 binding proteins in adrenal medulla. Binding of Fos/Jun complexes to the AP-1 sites in these genes has been demonstrated (Sonnenberg et al., 1989b; Gizang-Ginsberg and Ziff, 1990; Icard-Liebkalns, 1992). The Fos/Jun complex has been shown to stimulate transcription of the preproENK gene, whereas Fos/JunB complex had no effect on ENK transcription (Sonnenberg et al., 1989b). We have observed increased levels of both ENK and TH mRNAs after capsaicin and nicotine treatments (Pelto-Huikko et al., unpublished observations), and these two treatments cause a dramatic upregulation of IEG mRNAs which thus may be involved in the regulation of the $\mathrm{TH}$ and preproENK genes.

\section{Conclusions}

The present findings demonstrate that the basal levels for c-fos, c-jun, and jun B mRNAs and proteins are low in adrenal chromaffin cells and that several types of treatment activate their expression. Consistently with the low basal expression of AP-1 binding proteins the AP-1 DNA binding activity is low in control adrenals, whereas the binding activity is markedly increased after nicotine treatment. Reflex stimulation of splanchnic nerves with capsaicin combined with unilateral surgical denervation of the adrenal gland showed that the induction of IEG expression is dependent on neurotransmitters released from splanchnic nerve terminals. Treatments with nicotinic and muscarinic agonists and antagonists alone, or in combination with capsaicin indicated that $\mathrm{ACh}$ may be the major regulator of $\mathrm{c}-f o s$ induction. Also the increase in c-jun and jun B mRNAs may be caused by $\mathrm{ACh}$, since both nicotinic and muscarinic agonists induce their expression. However, we were unable to block the capsaicin-induced increase in c-jun mRNA, and since the combination of antagonists potentiated the increase in jun B, it is likely that another transmitter(s), in addition to $\mathrm{ACh}$, is released from splanchnic nerve terminals and regulates gene expression in adrenal medulla. Our conclusions are supported by previous findings showing noncholinergic transmission both in sympathetic ganglia (Ip et al., 1983; Zigmond, 1985; Schwarzschild and Zigmond, 1989) and adrenal medulla (Malhotra and Wakade, 1987; Fossom et al., 1991a,b; Schalling et al., 1991).

The IEGs showed stronger induction in adrenaline cells than in noradrenaline cells after the different treatments. This demonstrates that adrenal chromaffin cells are heterogenous in their response to external stimuli and that the signal transduction mechanisms may differ between adrenaline and noradrenaline cells.

\section{References}

Abate C, Curran T (1990) Encounters with Fos and Jun on the road to AP-1. Semin Cancer Biol 1:19-26.

Amann R, Lembeck F (1987) Stress induced ACTH relese in capsaicin treated rats. Br J Pharmacol 90:727-731. 
Angel P, Karin M (1991) The role of Jun, Fos and the AP-1 complex in cell-proliferation and transformation. Biochin Biophys Acta 1072: 129-157.

Angel P, Imagawa R, Chiu R, Stein B, Imbra J, Rahmsdorf H, Jonat C, Herrlich P, Karin M (1987) Phorbol ester-inducible genes contain a common cis element recognized by a TPA-modulated trans-acting factor. Cell 49:729-739.

Axelrod J (1971) Noradrenaline; fata and control of its biosynthesis. Science 173:598-606.

Bartel D, Sheng M, Lau L, Greenberg M (1989) Growth factors and membrane depolarisation activate distinct programs of early response gene expression: dissociation of fos and jun induction. Genes Dev 3:304-313.

Baruchin A, Vollmer RR, Miner LL, Sell SL, Stricker EM, Kaplan BB (1993) Cold-induced increases in phenylethanolamine $N$-methyltransferase (PNMT) mRNA are mediated by non-cholinergic mechanisms in the rat adrenal gland. Neurochem Res 18:759766.

Blottner D, Schmidt HHW, Baumgarten HG (1993) Nitroxergic autonomic neurons in rat spinal cord. Neuroreport 4:923-926.

Bohman D, Bos T, Admon A, Nishimura T, Vogt P, Tjian R (1987) Human proto-oncogene $c$-jun encodes a DNA binding protein with structural and functional properties of transcription factor AP-1. Science 238:1386-1392.

Bohn M, Kessler L, Golightly L, Black I (1983) Appearance of enkephalin-immunoreactivity in rat adrenal medulla following treatment with nicotinic antagonist or reserpine. Cell Tissue Res 231:496-499.

Bonner T, Buckley N, Young A, Brann M (1987) Identification of a family of muscarinic acetylcholine receptor genes. Science 237:527532.

Bredt DS, Snyder SH (1992) Nitric oxide, a novel neuronal mesenger. Neuron 8:3-11.

Bunn SJ, Marley PD, Livett BG (1988) The distribution of opioid binding subtypes in the bovine adrenal medulla. Neuroscience 27: $1081-1094$

Chavkin C, Cox BM, Goldstein A (1979) Stereospesific opiate binding in bovine adrenal medulla. Mol Pharmacol 15:751-753.

Cohen D, Curran T (1988) Fra-1: a scrum-inducible, ccllular immediate-early gene that encodes a fos-related antigen. Moll Cell Biol 8:2063-2069

Curran T, Franza BR (1988) Fos and Jun: the AP-1 connection. Cell 55:395-397.

Curran T, Gordon MB, Rubino KL, Sambucetti LC (1987) Isolation and characterization of the c-fos(rat) cDNA and analysis of posttranslational modification in vitro. Oncogene 2:79-84.

Dagerlind $\AA$, Friberg K, Bean AJ, Hökfelt T (1992) Sensitive mRNA detection using unfixed tissue: combined radioactive and non-radioactive in situ hybridixation histochemistry. Histochemistry 98:39-49.

Dagerlind $\AA$, Pelto-Huikko M, Lundberg J, Ubink R, Brimijoin S, Hökfelt $T$ (1994) Immunologically induced sympathectomy of preganglionic nerves by antibodies against acetylcholinesterase: increased levels of peptides and their mRNAs in the rat adrenal gland. Neuroscience, in press.

Deneris E, Connolly J, Rogers S, Duvoisin R (1991) Pharmacological and functional diversity of neural nicotinic acetylcholine receptors. Trends Pharmacol Sci 12:34-40.

Dynan WS (1989) Modularity in promoters and enhancers. Cell 58: $1-4$.

Fernando J, Abdallah E-S, Evinger M, Forray C, El-Fakahany E (1991) The presence of an M4 muscarinic receptor in the bovine adrenal medulla revealed by mRNA and receptor binding analyses. Eur J Pharmacol 207:297-303.

Fossom L, Carlson C, Tank W (1991a) Stimulation of tyrosine hydroxylase gene transcription by nicotine in rat adrenal medulla. Mol Pharmacol 40:193-202.

Fossom L, Sterling C, Tank W (199lb) Activation of tyrosine hydroxylase by nicotine in rat adrenal gland. J Neurochem 7:2070-2077.

Funder JW (1992) Glucocorticoid receptors. J Steroid Biochem Mol Biol 43:389-394

Gizang-Ginsberg E, Ziff EB (1990) Nerve growth factor regulators tyrosine hydroxylase gene transcription through a nucleo protein complex that contains c-Fos. Genes Dev 4:477-491.

Goc A, Norman S, Puchacz, Stachowiak E, Lukas R, Stachowiak M (1992) A 5 ' flanking region of the bovine tyrosine hydroxylase gene is involved in cell-specific expression, activation of gene transcription by phorbol ester, and transactivation by $\mathrm{c}$-fos and c-jun. Mol Cell Neurosci 3:383-394.

Greenberg ME, Ziff EB, Greene LA (1986) Stimulation of neuronal acetylcholine receptors induces rapid gene transcription. Science 234: 80-83.

Haby C, Lisovoski F, Aunis D, Zwiller J (1994) Stimulation of the cyclic GMP pathway by NO induces expression of the immediateearly genes c-fos and junB in PC12 cells. J Neurochem 62:496-501.

Hai T, Curran T (1991) Cross-family dimerization of transcription factors Fos/Jun and ATF/CREB alters DNA binding specificity. Proc Natl Acad Sci USA 88:3720-3724.

Herdegren T, Kovary K, Leah J, Bravo R (1991) Specific temporal and spatial distribution of Jun, Fos, and Krox-24 proteins in spinal neurons following noxious transsynaptic stimulation. J Comp Neurol 313:178-191.

Hirai S, Ryseck R-P, Mechta F, Bravo R, Yaniv M (1989) Characterization of JunD: new member of the jun proto-oncogene family. EMBO J 8:1433-1439.

Holzer P (1988) Local effector functions of capsaicin-sensitive sensory nerve endings: involvement of tachykinins, calcitonin gene-related peptide and other neuropeptides. Neuroscience 24:739-768

Icard-Liepkalns C, Biguet NF, Vyas S, Robert JJ, Sassone-Corsi P, Mallet $J$ (1992) AP-1 complex and c-fos transcription are involved in TPA provoked and trans-synaptic inductions of the tyrosine hydroxylase gene: insights into long-term regulatory mechanisms. J Neurosci Res 32:290-298.

Ip N, Perlman R, Zigmond R (1983) Acute transsynaptic regulation of tyrosine-3-monooxygenase activity in the rat superior cervical ganglion: evidence for both cholinergic and noncholinergic mechanisms. Proc Natl Acad Sci USA 80:2081-2055.

Jancso G, Kiraly E, Jancso-Gabor A (1977) Pharmacologically induced selective degeneration of chemosensitive primary sensory neurons. Nature 270:741-743.

Johnson DG, Araujo-Nogueira C (1981) A simple method of reducing the fading of immunofluorescence during microscopy. J Immunol Methods 43:439-450.

Kanamatsu T, Unsworth CD, Diliberto EJ, Viveros OH, Hong JS (1986) Reflex splanchnic nerve stimulation increases levels of proenkephalin A mRNA and proenkephalin A-related peptides in the rat adrenal medulla. Proc Natl Acad Sci USA 83:9245-9249.

Kilpatrick DL, Howells RD, Fleminger G, Udenfried S (1984) Denervation of rat adrenal glands markedly increases preproenkephalin mRNA. Proc Natl Acad Sci USA 81:7221-7223.

Koistinaho J (1991) Nicotine-induced fos-like immunoreactivity in rat sympathetic ganglia and adrenal medulla. Neurosci Lett 128:47-51.

Koistinaho I, Pelto-Huikko M, Sagar S, Dagerlind $\AA$, Roivainen R, Hökfekt T (1993) Differential expression of immediate-early genes in the superior cervical ganglion after nicotine treatment. Neuroscience 56:729-739.

Kondo H, Kuramoto H, Wainer BH, Yanaihara N (1985) Evidence for the coexistence of acetylcholine and enkephalin in the sympathetic preganglionic neurons in rat. Brain Res 335:309-314.

Kovary K, Bravo R (1991) Expression of different JUN and FOS proteins during G0 to G1 transition in mouse fibroblas's: in vitro and in vivo associations. Mol Cell Biol 11:2451-2459.

LaGamma EF, Adler JE, Black IB (1984) Impulse activity differentially regulates (leu)enkephalin and catecholamine sharacters in the rat adrenal medulla. Science 224:1102-1104.

LaGamma EF, White JD, Adler JE, Krause JF, McKelvy JF, Black IB (1985) Depolarization regulates adrenal preproenkephalin mRNA Proc Natl Acad Sci USA 82:8252-8255.

LaGamma EF, White JD, McKelvy JF, Black IB (1989) Transcriptional regulation of adrenal catecholamine and opiate peptide transmitter Mol Brain Res 5:17-22.

Lee W, Haslinger A, Karin M, Tjian R (1987) Activation of transcription by two factors that bind promoter and enhancer sequences of the human metallothionein gene and SV40. Nature 325:368-378

Lembeck F, Amann R (1986) The influence of capsaicin sensitive neurons on stress-induced release of ACTH. Brain Res Bull 16:541-543.

Lin YS, Carey M, Phasthne M, Green MR (1990) How different eukaryotic transcriptional activators can coopperate promiscuously. $\mathrm{Na}$ ture 345:359-361

Malhotra R, Wakade A (1987) Vasoactive intestinal polypeptide stimulates the secretion of catecholamines from the rat adrenal gland. $\mathbf{J}$ Physiol (Lond) 388:285-294. 
Mezey E (1989) Cloning of rat adrenal medullary phenylethanolamine $N$-methyltransferase. Nucleic Acids Res 17:2125.

Moncada S (1992) The 1991 Ulf von Euler Lecture. The L-arginine: nitric oxide pathway. Acta Physiol Scand 145:201-227.

Morgan JI, Curran T (1991) Stimulus-transcription coupling in the nervous system: involvement of the inducible proto-oncogenes fos and jun. Annu Rev Neurosci 14:421-451.

Nishina H, Sato H, Suzuki T, Sato M, Iba H (1990) Isolation and characterization of fra-2, an additional member of the fos gene family. Proc Natl Acad Sci USA 87:3619-3623.

O'Shea E, Rutkowski R, Kim P (1989) Evidence that the leucine zipper is a coiled coil. Science 243:538-542.

O'Shea E, Rutkowski R, Kim P (1992) Mechanism of the specificily in the Fos-Jun oncoprotein heterodimer. Cell 68:699-708.

Pelto-Huikko M (1989) Immunocytochemical localization of neuropeptides in the adrenal medulla. J Electron Microsc Tech 12:364 379.

Pelto-Huikko M, Salminen T (1987) Localization of calcitonin generelated peptide (CGRP) in chromaffin cells and nerve terminals in adrenal medulla. Exp Brain Res 16:73-77.

Pelto-Huikko M, Salminen T Hervonen A (1985) Localization of enkephalins in adrenaline cells and the nerves innervating adrenaline cells in rat adrenal medulla. Histochemistry 82:377-383.

Pelto-Huikko M, Dagerlind $\AA$, Ceccatelli S, Hökfelt T (1991) The immediate-early genes $c$-fos and c-jun are differentially expressed in the rat adrenal gland after capsaicin treatment. Neurosci Lett 126:163 166.

Pennypacker KR, Hong JS, Douglass J, McMillian MK (1992) Constitutive expression of AP-1 transcription factors in the rat adrenal. Effects of nicotine. J Biol Chem 267:20148-20152.

Rauscher F, Sambucetti L, Curran T, Distel R, Spiegelman B (1988) A common DNA binding site for Fos protein complexes and transcription factor AP-1. Cell 52:471-480.

Ryder K, Lau L, Nathans D (1988) A gene activated by growth factors is related to the oncogene v-jun. Proc Natl Acad Sci ISSA 85:14871491.

Ryder K, Lanahan A, Perez-Albuerne E, Nathans D (1989) JunD: a third member of the jun gene family. Proc Natl Acad Sci USA 86: $1500-1503$

Ryseck R-P, Bravo R (1991) C-jun, junB, and junD differ in their binding affinities to AP-1 and CRE consensus sequences: effect of FOS proteins. Oncogene 6:533-542.

Ryseck R-P, Hirai SI, Yaniv M, Bravo R (1988) Transcriptional activation of c-jun during the $\mathrm{GO} / \mathrm{Gl}$ transition in mouse fibroblasts. Nature 334:535-537.

Schalling M, Franco-Cereceda A, Hemsen A, Dagerlind $\AA$, Seroogy K, Persson H, Hökfelt T, Lundberg JM (1991) NPY and catecholamines in rat sympathetic neurons and adrenal gland: studies on expression, synthesis and axonal transport after pharmacological and experimental manipulations using hybridization techniques and radioimmunoassay. Neuroscience 41:753-766.

Schüle R, Evans R (1991) Cross-coupling of signal transduction pathways: zinc finger meets leuzine zipper. Trends Genet 7:377-381.

Schultzberg M, Lundberg JM, Hökfelt T, Terenius L, Tatemoto K, Carlqvist M, Mutt V (1978) Enkephalin-like immunoreactivity in galand cells and nerve terminals of the adrenal medulla. Neuroscience 3:1169-1186.

Schwarzschild M, Zigmond R (1989) Secretin and vasoactive intestinal peptide activate tyrosine hydroxylase in sympathetic nerve endings. J Neurosci 9:160-166.
Sheng M, Greenberg M (1990) The regulation and function of c-fos and other immediate-early genes in the nervous system. Neuron $4: 477-485$.

Sonnenberg JL, Michelmore C, Macgregor-Leon P, Hempstead J, Morgan J, Curran T (1989a) Glutamate receptor agonists increase the expression of Fos, Fra and AP-1 DNA binding activity in the mammalian brain. J Neurosci Res 24:72-80

Sonnenberg JL, Rauscher FJ, Morgan JI, Curran T (1989b) Regulation of proenkephalin by Fos and Jun. Science 246:1622-1625.

Stachowiak M, Goc A (1992) Regulation of gene expression in catccholamine and opioid synthesis in sympathoadrenal system-nuclear mechanisms and second messenger systems. In: Advances in the innervation of the gastrointestinal tract (Holle et al., eds), pp 251-263. London: Elsevier.

Stachowiak M, Goc A, Hong J, Kaplan B, Stachowiak E (1990a) Neuronal and hormonal regulation of the tyrosine hydroxylase gene in adrenal medullary cells: participation of c-fos and AP1 factors. Mol Cell Neurosci 1:202-213.

Stachowiak MK, Sar M, Tuominen RK, Jiang HK, An S, Iadarola MJ, Poisner AM, Hon JS (1990b) Stimulation of adrenal medullary cells in vivo and in vitro induces expression of c-fos proto-oncogene. Oncogene 5:69-73.

Thoenen $H$ (1975) Transynaptic regulation of neuronal enzyme synthesis. In: Handbook of psychopharmacology, Vol 3 (Iversen LL, Iversen SD, Snyder S, eds), pp 443-475. New York: Plenum.

Trejo J, Chambard J-C, Karin M, Brown JH (1992) Biphasic increase in c-jun mRNA is required for induction of AP-1-mediated gene transcription: differential effects of muscarinic and thrombin receptor activation. Mol Cell Biol 12:4742-4750.

Vogt PK, Bos 'IJ (1990) jun: oncogene and transcription factor. Adv Cancer Res 55:1-35.

Wan D, Livett B (1992) Independent control of gene expression in costored regulatory transmitters. In: Advances in the innervation of the gastrointestinal tract (Holle et al., eds), pp 265-272. London: Elsevier.

Warashina A, Fujiwara N, Shimoji K (1989) Characteristics of nicotinic and muscarinic secretory responses in the rat adrenal medulla studied by real-time monitoring of catecholamine release. Biomed Res 10: $157-164$

Watanabe T, Kawada T, Kurosawa M, Sato A, Iwai K (1988) Adrenal sympathetic efferent nerve and catecholamine secretion excitation caused by capsaicin in rats. Am J Physiol 25:E23-E27.

Weisberg EP, Baruchin A, Stachowiak MK, Stricker EM, Zigmond MJ, Kaplan BB (1989) Isolation of a rat adrenal cDNA clone encoding phenylethanolamine $N$-methyltransferase and cold-induced alterations in adrenal PNMT mRNA and protein. Mol Brain Res 6:159-166.

Wessel TC, Joh TH (1992) Parallel upregulation of catecholaminesynthesizing enzymes in rat brain and adrenal gland: effects of reserpine and correlation with immediate-early gene expression. Brain Res Mol Brain Res 15:349-360.

Young ST, Porrino LS, Iadarola MS (1991) Cocain induces striatal c-fos-immunoreactive proteins via dopaminergic D1 receptors. Proc Natl Acad Sci USA 88:1291-1295.

Zerial M, Toschi L, Ryseck R-P, Schuermann M, Müller R, Bravo R (1989) The product of a novel growth factor activated gene, fos $B$ interacts with JUN proteins enchancing their DNA binding activity. EMBO J 8:805-813.

Zigmond RE (1985) Biochemical concequences of synaptic stimulation: the regulation of tyrosine hydroxylase activity by multiple transmitters. Trends Neurosci 8:63-69. 